\title{
Artikkeli
}

\section{Haavoittuvuuden kudelmat}

\section{Digitaalinen subjekti ja haavoittuvuus datavetoista yhteiskuntaa käsittelevässä tutkimuskirjallisuudessa}

\begin{abstract}
Artikkelissa tarkastellaan sitä, millaisia merkityksiä haavoittuvuudelle on annettu datavetoista yhteiskuntaa ja digitaalista subjektia koskevassa tutkimuskirjallisuudessa. Artikkeli perustuu kirjallisuuskatsaukseen, joka on tehty vuosina 20152020 ilmestyneistä haavoittuvuutta datafikaation kontekstissa käsittelevistä tieteellisistä julkaisuista. Kirjallisuushaut tehtiin yhteiskuntatieteiden alojen keskeisistä tietokannoista ja digitaalisista kirjastoista. Hakujen pohjalta tutkimuskirjallisuus järjestettiin neljään teemakokonaisuuteen: 1) datavalvonnan tuottamat haavoittuvuudet, 2) data tietämisen tapana ja osallisuutena, 3) digitaalisten subjektien kategorisointi ja näkyvyyden säätely sekä 4) haavoittuvuus suhteessa autonomiaan ja ontologiaan. Kartoitetun tutkimuskirjallisuuden perusteella datan kerääminen ja digitaaliset toimintaympäristöt tuottavat haavoittuvuutta, joka ilmenee niin subjektien muotoutumisessa, näkyvyydessä, kategorisoinnissa, osallisuudessa, suhteissa kuin digitaalisen olemassaolon ontologisessa luonteessa. Artikkelissa esitetään, että haavoittuvuuden käsitettä olisi hyvä hyödyntää teoreettisena työkaluna, jonka avulla tutkia datafikaatioon liittyviä mahdollisuuksia ja toiminnan ehtoja. Haavoittuvuuden kokemuksellisuutta datasuhteissa voitaisiin lähestyä tunnerakenteena ja eettisenä resurssina.
\end{abstract}

AVAINSANAT: haavoittuvuus, datafikaatio, datatutkimus, digitaalinen subjekti, datasuhde

$\mathrm{D}$ igitaaliset alustat ja laitteet ovat kasvavassa määrin läsnä ihmisten koko elämän kirjossa. Tässä artikkelissa haluamme ymmärtää moninaisia tapoja elää ja toimia digitalisoituneessa ja dataistuneessa ympäristössämme. Julkisessa keskustelussa on kritisoitu datan ja data-alustojen keskeisyyttä sosiaalisen todellisuutemme rakentumisessa. Suomessa etenkin Vastaamon tietomurto ja yksityisten potilastietojen vuotaminen data-alustoille on nostanut esiin ajatuksen alustojen, datan ja datan kierron aiheuttamasta yksilön haavoittuvuudesta. Artikkelillamme pyrimme avaamaan suomenkielistä keskustelua haavoittuvuudesta digitaalisen subjektin ja datasuhteiden näkökulmasta.

Tutkimme, mitä datafikaatiota käsittelevässä kirjallisuudessa tarkoitetaan haavoittuvuudella ja millaisiin keskusteluihin se liitetään. Keskitymme dataistuvaa yhteiskuntaa ja mediaa sekä digitaalista subjektiutta käsitteleviin tutkimuksiin. Tarkoitamme dataistuneella 
medialla hyvin laaja-alaisesti datavetoisen kulttuurin toimintaympäristöjä, media-alustoja, palveluja, laitteita, sovelluksia ja sisältöjä, joiden avulla digitaalinen subjekti muotoutuu ja toimii (ks. Lomborg, Dencik ja Moe, 2020; Andrejevic 2019, 9-10). Tähän mennessä datafikaation ja dataistuneen median tutkimuksessa haavoittuvuus on noussut usein esiin valvonnan kontekstissa. Vähemmälle huomiolle on jäänyt haavoittuvuuden tarkastelu elettyjen kokemusten ja digitaalisten subjektien näkökulmasta (Kennedy 2018). Kriittisessä mediatutkimuksessa on ehdotettu haavoittuvuuden käsitettä käytettäväksi silloin, kun halutaan ymmärtää dataistuneessa kulttuurissa esiin tulevia kielteisiä kokemuksia tai valtapositioita (Lutz 2019).

Käytämme käsitettä digitaalinen subjekti viittaamaan alustoilla syntyviin toimijuuksiin. Läpikäymässämme kirjallisuudessa käytetään myös monia muita toimijuuteen liittyviä käsitteitä, kuten toimijapositio, subjektipositio, (järjestelmä)käyttäjä, datasubjekti tai datafioitu subjekti. Digitaalisella subjektilla tarkoitamme monikerroksista suhteiden kudelmaa, joka syntyy ihmisten ja datan suhteisiin kytkeytyvistä toimijuuksista. Goriunova (2019) kuvailee digitaalista subjektia abstraktina toimijuutena, jolla on yhteydet eläviin yksilöihin (sekä sosiaalipoliittisiin, oikeudellisiin, psykologisiin, teknologisiin, kulttuurisiin ja yleensäkin tieteellisiin jäsennyksiin), mutta joka on olemassa vain suhteessa dataan ja alustoihin.

Kysymme tutkimuksessa, miten haavoittuvuus on ymmärretty suhteessa datafikaatioon ja sen erilaisiin konteksteihin, millaisissa keskusteluissa siitä puhutaan ja mitä haavoittuvuuden käsitteellä keskusteluissa tehdään. Rajaamme tarkastelumme siihen, miten digitaalisten subjektien haavoittuvuutta on problematisoitu vuosina 2015-2020 ilmestyneissä tieteellisissä julkaisuissa. Toivomme, että artikkeli toimii avauksena suomenkieliseen teoreettiseen keskusteluun haavoittuvuuden eri ulottuvuuksista dataistuneen median kontekstissa.

\section{Datafikaation teoreettinen tausta}

Datafikaation käsitteellä viitataan käynnissä olevaan murrokseen, jolle on leimallista datan kasvava määrä, sen pohjalta tuotettu tieto ja tämän datapohjaisen tiedon laaja-alainen ja yksilön elämään vaikuttava hyödyntäminen teknologiayritysten tuottamista yksittäisistä palveluista aina yhteiskunnalliseen päätöksentekoon asti. (Kennedy 2018; Couldry ja Yu 2018). Digitaalisia ympäristöjämme muokataan yhä enemmän meistä kerätyn ja luovuttamamme datan perusteella (Kennedy 2018), kun entistä suurempi osa aktiviteeteistamme jättää digitaalisia jälkiä data-analytiikan pohjaksi. Datan prosessointi tiedoksi ja sitä kautta toiminnaksi ei toki tapahdu ainoastaan yksilöiden aktiivisesti käyttäessä digitaalisia laitteita ja sovelluksia. Datafikaatio on nähty laajemmin sosiaalisen todellisuuden medioitumiseen liittyvänä prosessina (Couldry ja Hepp 2017). Kyse on merkittävästä ihmisten elämään kohdistuvasta muutoksesta, jossa yksilöiden toimintaa hyödynnetään kasvavassa määrin datan lähteenä. Taustalla voidaan nähdä ajatus siitä, että datan avulla on mahdollista päästä lähemmäksi "totuutta" (Taylor 2020; van Dijck 2014), miten se sitten missäkin kontekstissa määritellään. Van Dijck (2014) esittää, että tällaista keskustelua hallitsee positivistinen objektiivisuuden ja rationaliteetin retoriikka, missä nimenomaan datan muuttamisen numeroiksi ajatellaan tuottavan todellista tietoa. Datan määrä ja sen lisääminen nähdään tällöin 
tärkeänä, mihin viitataan toisinaan niin sanottuna big data -paradigmana (Kitchin 2014). Myös datan käsittelyn tavat ovat keskeisiä. Esimerkiksi Chun (2016b, 374) huomauttaa, että big dataa hyödyntävässä analytiikassa on tyypillistä sovittaa yhteen toisistaan riippumattomia korrelaatioita, joiden avulla voidaan pyrkiä tuottamaan haluttu lopputulos. Datan keräämiseen sisältyy usein epistemologisia ja ontologisia taustaoletuksia, jotka muuttavat niin tieteellisen tiedon tuottamista ja legitimiteettiä kuin subjektien muodostumista (Hintz, Dencik ja Wahl-Jorgensen 2018, 6; Corple ja Linabary 2020).

Datafikaation vaikutuksia ja seurauksia on tarkasteltu empiirisesti eri tutkimuskentillä. Esimerkiksi van Dijckin (2014) keskeinen datafikaation kritiikki liittyy juuri datahallintaan, jossa niin yksityiset kuin julkiset instituutiot käsittelevät, yhdistelevät ja tekevät päätöksiä ihmisten alustoille jättämän (meta)datan perusteella. Usein ihmiset eivät kuitenkaan ole itse tietoisia taustalla vaikuttavista prosesseista. Andrejevic (2019) puolestaan esittää, että datafikaation prosessien taustalla on usko datan ennustamisvoimaan ja algoritmien ennalta määrittelemään tulevaisuuteen. Tällöin yksilön väärä toiminta pystytään estämään jo ennen kuin mitään järjestelmän kannalta epäedullista tapahtuu. Tämä on Andrejevicin (2019) mukaan teknologista idealismia selkeimmillään; usko siihen, että subjektin tietäminen ja halu voidaan ratkaista, kunhan (yksilöstä kerätty) data ja siihen liittyvät prosessit ovat riittävän tarkasti spesifioitu ja ennalta määritelty. Yksilötasolla ennaltamäärittelyn pyrkimys näkyy toimintahorisontin kapenemisena, mutta toisaalta subjektien ristiriitaiset halut eivät taivu kaikilta osin datajärjestelmien logiikkaan.

Kun on haluttu ymmärtää, minkälaista toimijuutta dataistuminen tuottaa, on puhuttu niin sanotusta datafioituneesta yksilöstä (Barassi 2019; Lupton 2019). Datasta tuotettu toimijuuspositio onkin keskeinen silloin, kun haavoittuvuutta tarkastellaan datafikaation kontekstissa. Myös Andrejevicin (2019) ajatus automatisoidusta mediasta johtaa dataistuneen ja medioituneen digitaalisen subjektin ajatukseen. Hänen mukaansa inmisten kokemukset muotoutuvat nykyään verkottuneen median kautta (esim. terveyssovellukset), jolloin subjektin tässä hetkessä ja tulevaisuudessa tapahtuvaa toimintaa tulkitaan ja muokataan datan avulla. Kun taas datafikaatiota on tarkasteltu elettyinä kokemuksina dataistuneessa ympäristössä, huomiota on kiinnitetty affektien keskeisyyteen ihmisten aktiviteeteissa ja kohtaamisissa datan ja digitaalisten laitteiden kanssa (Sumartojo ym. 2016)

Yksilöstä kerättävää dataa on lähestytty hallinnan sekä hallinnan tuottaman epätasaarvon näkökulmasta (Gangadharan 2012; Eubanks 2018). Vastaavasti yksilön nimeämistä haavoittuvaksi voidaan pitää eräänlaisena hallinnan keinona (Cole 2016, 261). Datavetoisen kulttuurin tuottamia ongelmia on analysoitu erityisesti syrjinnän ja eriarvoisuuden näkökulmista. Favaretton ja kumppanien (2019) systemaattinen kirjallisuuskatsaus osoittaa, että datasyrjintää on saattanut ilmetä esimerkiksi työnhaussa ja luottopisteytyksessä. Eubanks (2018) taas analysoi yhdysvaltalaisessa kontekstissa algoritmeihin perustuvan päätöksenteon tuottamaa epätasa-arvoa ja haavoittuvuutta. Hänen mukaansa jo valmiiksi heikommassa asemassa olevista ryhmistä kerätään dataa suhteellisesti enemmän kuin muista ja tämän pohjalta tehdään todennäköisyyksiin perustuvia päätöksiä. Tätä toimintatapaa Eubanks kuvaa termillä kaksinkertainen haavoittuvuus. Näin vaikkapa rikollisuuden ilmenemistä voidaan ennustaa tietyssä väestönosassa, johon sitten voidaan kohdistaa ennakoivia toimia. Syrjintä on näin ollen liitetty usein valmiiksi heikossa asemassa - tai haavoittuvina - pidettyihin ryhmiin, joille datakäytännöistä seuraa lisää ongelmia. 
Hallinnan tai epätasa-arvon sanastot eivät kuitenkaan kata kaikkia erilaisia toimijuuspositioita, joita dataistuneessa kulttuurissa syntyy. Näitä moninaisia positioita voidaan ajatella Leen (2021) mukaan datasuhteina. Ne ovat paitsi yksilön kokemusta itsestä myös suhteita erilaisiin data-alustoihin ja datan kiertoon alustojen ja yksilöiden välillä. Kirjallisuudesta vaikuttaa kuitenkin puuttuvan näkökulmia, joissa näitä datasuhteita, niiden muuttuvuutta ja seurauksia käsiteltäisiin yksilöiden näkökulmasta. Tässä artikkelissa emme ole kiinnostuneita pelkästään kielteisistä kokemuksista vaan niistä erilaisista tavoista, joilla luomme dataan ja datan kautta suhteita ja joilla niitä datan avulla mahdollisesti luodaan meihin. Näissä suhteissa myös digitaalinen subjektiviteettimme muotoutuu. Lähestymistapa auttaa tunnistamaan haavoittuvuuteen liittyvää moninaisuutta ja jäsentämään digitaalisen elämisen ontologiaa sellaisella tavalla, joka ylittää totutut dikotomiat datatalouden kielteisistä tai myönteisistä vaikutuksista. Seuraavaksi esittelemme haavoittuvuuden käsitteen teoreettisen pohjan. Tämän jälkeen tarkastelemme sitä, miten tutkimuksessa on tähän mennessä keskusteltu digitaalisten subjektien tunnekokemuksista alusta-ajassa.

\section{Haavoittuvuus ja digitaalisten subjektien kokemuksellisuus}

Haavoittuvuuden käsitettä on käytetty laajalti eri tieteenaloilla viime vuosikymmeninä. Tyypillisesti termi on sidottu populaatioihin tai väestöryhmiin, jotka erottuvat niin sanotusta valtaväestöstä tai joita mahdollisesti määrittää jokin toimintaa rajoittava puute, esimerkiksi taloudellisessa niukkuudessa tai riippuvuussuhteissa eläminen. Poliittisessa keskustelussa ja sosiaalityön käytännöissä haavoittuvuudella viitataan yleensä yksilöihin tai ryhmiin, jotka tarvitsevat tukea sosiaalisissa, terveydellisissä tai taloudellisissa ongelmissa (Virokannas, Liuski ja Kuronen 2020). Myös lapsia ja iäkkäitä kuvataan usein haavoittuviksi (Fineman 2008, 6; Nikander ja Zechner 2006, 515). Koivusen ja kumppanien (2018) mukaan humanististen ja yhteiskuntatieteiden sekä feministisen ja queer-tutkimuksen suuntautuminen etiikan, ruumiillisuuden, affektin ja ontologian kysymyksiin on lisännyt kiinnostusta haavoittuvuuden käsitteeseen. He paikantavat käsitteen tieteidenvälisen liikehdinnän alkuvaiheen moraalifilosofian ja poliittisen filosofian kentille 1980-luvulle, minkä jälkeen sitä on tarkasteltu monilla tieteenaloilla, kuten sosiologiassa, oikeusteoriassa, etiikan tutkimuksessa, ympäristötutkimuksessa, feministisessä filosofiassa ja mediatutkimuksessa. Haavoittuvuus on saanut eri aloilla vaihtelevia merkityksiä ja tulkintoja, mutta sitä on myös pidetty kiistanalaisena käsitteenä.

Mediatutkimuksessa, feministisessä tutkimuksessa ja laajemmin yhteiskuntatieteissä tutkimuskentät, joihin myös tekstin kirjoittajina vahvimmin paikannumme - haavoittuvuus ymmärretään usein ontologiaan kytkeytyvänä käsitteenä. Haavoittuvuus on toisin sanoen olotila, jonka kaikki ihmiset jakavat. Fineman (2008) on ehdottanut, että tällainen näkemys haavoittuvuudesta haastaa yksiulotteista liberaalin yksilön paradigmaa, jossa ihmiset nähdään herkästi joko autonomisina ja pärjäävinä yksilöinä tai vastaavasti avun tarvitsijoina. Finemanin mukaan sellaiset institutionaaliset käytännöt, jotka pyrkivät reagoimaan haavoittuvina pidettyjen ihmisryhmien olotilaan, tuottavat itsessään luonnollistettua ajatusta haavoittuvista joukoista. Toisaalta ajatus haavoittuvuudesta ontologisena ihmiselämän perustana on saanut feministisen tutkimuksen sisällä myös kritiikkiä, koska ihmisten 
sosiaaliset asemat eroavat todellisuudessa suuresti. Cole $(2016,266)$ peräänkuuluttaakin episteemisen haavoittuvuuden termillä, kuinka empiirisessä tutkimuksessa tarvitaan tietoa eriarvoisuutta ja haittaa lisäävistä haavoittuvuuksista. Koivusen ja kumppanien (2018) mukaan haavoittuvuus liitetään läntiseen 2000-luvun ajankuvaan, jolloin siitä muotoutuu taustalla vaikuttava tunne ja odotus. Turvallisuuden lisääminen - esimerkiksi laaja-alaisella datavalvonnalla toteutettuna - puolestaan nähdään nykyajan vastauksena tämänkaltaiselle ambivalentille haavoittuvuudelle (ks. Cole 2016, 264).

Dencik (2018) esittää, että datavetoisesta kulttuurista puhuttaessa olisi välttämätöntä luoda vastapainoa sitä hallitsevalle valvontarealismille ja sen itsestäänselvyydelle. Hän ehdottaa kuvittelemaan vaihtoehtoisia mahdollisuuksia ja yhteiskunnallisia toimintatapoja kasvavan datavalvonnan haastajaksi. Haavoittuvuuden näkökulmasta on olennaista tarkastella, miten yksilöllistä kokemusta on sanoitettu dataistuvaa yhteiskuntaa käsittelevissä teksteissä. Kennedyn $(2018,18)$ mukaan datan keruun ja sen varastoimisen räjähdysmäisestä kasvusta huolimatta on pohdittu yllättävän vähän sitä, mitä ihmiset datasta, sen keräämisestä ja hyödyntämisestä ajattelevat. Tämä johtuu siitä, että datakäytäntöihin liittyvien tunteiden ja kokemusten tutkiminen on haastavaa. Eri toimijoiden datakäytännöt ovat ensinnäkin usein läpinäkymättömiä ja toiseksi tiettyjä tietoteknisiä termejä, kuten algoritmia, voidaan pitää monimerkityksellisinä ja liikkeessä olevina. (Steedman, Kennedy ja Jones 2020, 822-823; Seaver 2017.) Esimerkiksi Ruckensteinin ja Granrothin $(2020,17)$ tutkimukseen osallistuneiden ymmärrys algoritmeista liittyi kiinteästi siihen, miten algoritmeista puhutaan koulussa, mediassa ja ystävien kesken. Niin algoritmien kuin ihmisistä kerättävän ja ihmisten tuottaman datan kasvanut rooli on osaltaan tuottamassa haavoittuvuutta, mutta yhtä lailla ihmisten tavat toimia dataistuneessa mediaympäristössä ja niihin liitetyt merkitykset vaikuttavat siihen, millaisissa tilanteissa ja suhteissa haavoittuvuutta tunnistetaan ja kohdataan.

Vaikka tutkimusasetelmat ja metodit eroavat eri tutkimuksissa, digitaalisten subjektien kokemuksissa ovat toistuneet verrattain usein pelon ja epätietoisuuden tunnesanastot (Lupton ja Michael 2017, 266; Ruckenstein ja Granroth 2020, 18). Luptonin ja Michaelin tutkimuksessa (2017) osallistujat käsittelivät ja myös kuvittelivat yhdessä erilaisia datakäytäntöjä ja dataa prosessoivia laitteita. Tutkijoiden mukaan osallistujat eivät kuitenkaan osanneet tarkemmin artikuloida sitä, millaisia seurauksia datan keräämisellä ja datan liikkuvuudella voisi olla. Shklovski ja kumppanit (2014) toteavat puolestaan, että sovellukset tuntuvat karmivilta, epämiellyttäviltä tai "kuumottavilta” (creepy), koska niiden datan keruu ei näy ulospäin ja koska käyttäjät eivät ole täysin selvillä millaista dataa laitteet keräävät, mitä datalla tehdään ja kenen toimesta.

Kysymys yksityisyydestä on kenties merkittävin kiintopiste, jonka läpi datafikaatioon ja datavalvontaan liittyviä huolia on niin mediassa kuin tutkimuksessa käsitelty (ks. Sirkkunen 2016). Kun internettutkimuksessa on haluttu kiinnittää huomiota digitaalisen subjektin kokemukseen, nimenomaan yksityisyyteen liittyvät kysymykset ovat nousseet esille. Tässä yhteydessä on puhuttu yksityisyysparadoksista eli siitä, että ihmisillä on huoli omasta yksityisyydestä, vaikka heidän käytöksensä verkossa ilmentäisikin päinvastaista (ks. Barnes 2006; Draper ja Turow 2019). Shklovskin ja kumppanien $(2014,2354)$ mukaan yksityisyysparadoksin käsite ei kuitenkaan tavoita nykyistä tilannetta, jossa ihmiset kyllä haluavat enemmän kontrollia ja läpinäkyvyyttä, mutta kokevat, etteivät voi vaikuttaa asioihin. 
Tyypillisesti ihmiset pitävät erilaisia datakäytäntöjä vähäisempänä huolena silloin, kun he kokevat, ettei heillä itsellään ole piiloteltavaa (Ajana 2020, 21; Ruckenstein ja Granroth 2020, 18; Hintz, Dencik ja Wahl-Jorgensen 2018, 114). "Ei piiloteltavaa, ei pelättävää" -ajatus liittyy erityisesti kysymykseen yksityisyydestä ja yksityisyyden loukkaamisesta. Ajatusta voi WahlJorgensenin ja kumppaneiden $(2017,752)$ mukaan pitää arkijärkisenä vastauksena erilaisten yhteiskunnallisten uhkien torjunnalle ja minimoimiselle. Dencik (2018) luonnehtii datavalvonnan ympärillä kiertävää diskurssia valvontarealismiksi, jolle on enää vaikea kuvitella vaihtoehtoja, vaikka dataa keräämällä harjoitettu valvonta rajoittaakin ihmisten vapautta. Tätä ilmiötä voidaan kutsua myös datadoksaksi, jolla viitataan siihen, että datan keräämisestä ja jakamisesta on tullut luonnollistettua, normaalia ja välttämättömäksi koettua (Smith 2018). Kun datasta tulee doksa, myös siihen liittyvä valtadynamiikka luonnollistuu.

Subjektin kokemusta dataistuvasta yhteiskunnasta ja siihen liittyvää tunnemaisemaa jäsennetään myös luottamuksen termillä. Steedman ja kumppanit (2020) tarkastelevat ihmisten kokemuksia institutionaalisista datakäytännöistä ja liittävät ne ympäristön ja vuorovaikutuksen muodostamiin monimutkaisiin suhteisiin. Heidän mukaansa ihmisten huolet liittyen datan keräämiseen, prosessointiin ja kiertoon voivat aiheuttaa sen, että tiettyjen instituutioiden datakäytäntöihin ei luoteta, vaikka itse instituutiota pidettäisiin arvossa. Tutkimustulokset osoittavat, että kahtiajako luottamukseen ja epäluottamukseen ei tavoita kyllin selkeästi inmisten suhtautumista institutionaalisten toimijoiden tapaan käsitellä dataa, kun pelissä on samanaikaisesti laajempi dataympäristö.

Aiempi tutkimus viittaa myös siihen, että datafikaatioon liittyviä kuluttajien ja kansalaisten kokemuksia ei pidä ymmärtää yksioikoisesti huolten ja kielteisyyden kautta. Ihmiset pitävät esimerkiksi kohdennetun mainonnan osuvuudesta ja ajankohtaisuudesta (Ruckenstein ja Granroth 2020, 20). Luptonin ja Michaelin (2017, 263) tutkimukseen osallistuneet keksivät datavalvonnalle myönteisiä puolia, joiden pohjalta datan omistajuus on hyötyjen ja haittojen arvioinnin näkökulmasta keskeistä. Ajanan (2020) tutkimus itsensä mittaamisesta tuotti vastaavia tuloksia. Ihmiset kokevat henkilökohtaista dataa tuottavat laitteet ja sovellukset omaa terveyttään parantaviksi, eivätkä he ole kovinkaan huolissaan yksityisyyteen ja dataan keräämiseen liittyvistä kysymyksistä. Tästä poikkeuksena olivat kuitenkin yhdysvaltalaiset vastaajat, jotka olivat huolissaan siitä, että vakuutusyhtiöt saattaisivat käyttää dataa heitä vastaan (emt., 18).

Datan keräämiseen, käyttöön ja valvontaan liittyvä tutkimus osoittaa eri näkökulmista, miten digitaalista subjektia valvotaan, hallitaan, määritellään ja ohjaillaan datan kautta. Toisaalta tutkimus osoittaa, kuinka datan keruun voidaan myös kokea helpottavan elämää tai parantavan sen laatua. Seuraavaksi avaamme metodologisia ratkaisuja, joiden pohjalta rakensimme oman analyysimme haavoittuvuudesta datafikaation kontekstissa.

\section{Metodologia}

Analyysissä tarkastelemme, millaisia haavoittuvuuksia digitaalisiin subjekteihin ja toimintaympäristöihin on liitetty ja miten haavoittuvuuden käsitettä on määritelty datafikaation kontekstissa yhteiskunta- ja viestintätieteellisessä tutkimuksessa. Datafikaation kontekstilla tarkoitamme datavetoisesti toimivia mediaympäristöjä ja niihin liittyvää datan keräämistä ja 
kiertoa sekä niissä muodostuvia toimijuuksia. Tässä mielessä sovitamme yhteen datafikaation tutkimusta ja digitaalisen subjektiuden haavoittuvuuteen liittyvää tutkimusta.

Lähdimme liikkeelle perehtymällä aihepiiristä löytyvään kirjallisuuteen, jotta saisimme muodostettua ilmiöstä tarvittavan laajan kuvauksen (ks. Salminen 2011, 6). Emme pyrkineet kattavan kirjallisuuskatsauksen tekemiseen vaan löytämään sellaista haavoittuvuutta käsittelevää tutkimuskirjallisuutta, jossa yksilöiden kokemusten moninaisuutta ja neuvottelua suhteessa dataan ja datafikaatioon tuotaisiin esille erilaisissa arjen konteksteissa. Valitsimme aluksi käytettävät tietokannat sekä relevantit hakutermit. Kävimme läpi merkittävät yhteiskunta- ja viestintätieteiden tietokannat, joita olivat EBSCO (Communication \& Mass Media Complete ja Sociology Source Ultimate), JSTOR, ProQuest (Social Science Premium Collection) ja ISI Web of Science. Lisäksi suoritimme haut kahden merkittävän julkaisijan, SAGE:n ja Taylor \& Francisin (Online) tietokannoista. Kävimme myös läpi suomalaiset lehtitietokannat, Arton, Elektran ja Journal.fi:n, jotka eivät kuitenkaan tuottaneet olennaisia tuloksia. Käytimme kolmea eri hakulauseketta. Useita hakulausekevaihtoehtoja testattiin kaikissa tietokannoissa ennen varsinaisia hakuja, ja lopullisiksi termeiksi valittiin:

(datafication OR dataveillance OR dataism) AND vulnerability*

"digital vulnerability"

("digital divide" OR "digital inequality") AND vulnerability*

Tehdyt haut erosivat toisistaan jossain määrin riippuen tietokantojen ominaisuuksista. Pyrimme rajaamaan hakuja julkaisujen abstrakteihin ja asiasanoihin, mutta kaikissa tietokannoissa näitä toimintoja ei ollut mahdollista käyttää. Tämän vuoksi tekstien käytännön seulonta riippui myös siitä, kuinka tarkasti hakulausekkeita oli mahdollista täsmentää. Suomenkielisten tekstien lisäksi rajasimme haut koskemaan englanniksi kirjoitettuja vertaisarvioituja artikkeleita ja kirjalukuja tammikuusta 2015 joulukuuhun 2020. Lisäksi täydensimme aineistoa manuaalisen haun menetelmällä käyttäen apuna datafikaatiota käsittelevien julkaisujen ja jo haettujen artikkeleiden kirjallisuusviitteitä.

Emme asettaneet artikkeleille metodologista seulaa kuten edellyttäneet niiden käsittelevän tiettyjä aihepiirejä tietyistä empiirisistä tai teoreettisista asetelmista käsin. Julkaisuilta ei myöskään vaadittu haavoittuvuuden käsitteellistä pohdintaa tai määrittelyä. Pidimme kiinni siitä, että artikkelien tuli liittyä datavetoisen kulttuurin ilmiöiden tutkimiseen nykymaailmassa. Toiseksi edellytimme, että terminä haavoittuvuus esiintyy teksteissä useammin kuin kerran ja että se liitetään ihmisiin, heidän toimijuuteensa tai kokemuksiinsa. Seulontaprosessimme oli tästä huolimatta tulkinnallinen, jolloin kirjoittajien välinen keskustelu ja näkemysten yhteensovittaminen oli olennainen osa tekstien seulontaa.

Aihealueiden näkökulmasta löyhä seula tarkoitti sitä, että katsaukseemme valikoitui niin viestinnän ja median tutkimusta, sosiologista tutkimusta, feminististä tutkimusta, queertutkimusta, oikeus- ja terveystieteisiin paikantuvaa tutkimusta, kuluttajatutkimusta kuin kulttuurimaantiedettäkin. Terveyssovelluksia ja terveyttä käsittelevä tutkimus näyttäytyy melko hallitsevana tutkimusalueena datafikaatiotutkimuksessa, mutta omaan tarkasteluumme valikoimme soveltuvin osin mukaan vain sellaista terveyteen ja hyvinvointiin liittyvää tutkimusta, jossa oli kyse haavoittuvuudesta joko osana digitaalista subjektiutta tai oman datan tuottamista.

Analyysilukujen kirjoittamiseksi pohdimme ensin aineiston aihealuepohjaista ryhmittelyä. Koska haavoittuvuuteen ja digitaaliseen subjektiuteen sisältyvät käsitykset ja keskuste- 
lut olivat aihealueiden sisällä kuitenkin kovin erilaisia, muodostimme temaattiset kokonaisuudet, joiden sisällä vallitsee samantapainen näkökulma haavoittuvuuteen. Näiden näkökulmien muodostamiseksi luimme ensin kaikki kriteerejämme noudattavat tekstit jakaen ne neljän kirjoittajan kesken. Tämän jälkeen muodostimme yhdessä neljä teemaa, jotka kattoivat julkaisujen pääasialliset lähestymistavat datafikaation kontekstissa kuvattuun haavoittuvuuteen. Analyysiprosessin seuraavassa vaiheessa kukin kirjoittaja sijoitti lukemansa tekstit tietyn teeman alle ja otti päävastuun yksittäisen teemakokonaisuuden tekstien lähiluennasta ja osion kirjoittamisesta, minkä jälkeen tulkinnat tarkistettiin kaikkien kirjoittajien kesken. Joidenkin tekstien osalta teemoittelu edellytti useita lukukertoja. Julkaisujen joukossa on myös tekstejä, joita voisi hyvin käsitellä useamman kuin yhden teemakokonaisuuden alla.

Samoja teemoja tarkasteltiin eri tieteenalojen sisällä eri näkökulmista, mutta myös yksittäisten artikkelien näkökulmat vaihtelivat. Aineistolähtöisen teemoittelun avulla tuotimme kukin teemoitteluun perustuvan tarkemman listauksen siitä, millaiset haavoittuvuuden näkökulmat teksteissä korostuvat. Näiden lähiluenta- ja tulkintakierrosten jälkeen nimesimme neljä teemakokonaisuutta: 1) datavalvonnan tuottamat haavoittuvuudet, 2) data tietämisen tapana ja osallisuutena, 3) digitaalisten subjektien kategorisointi ja näkyvyyden säätely, ja 4) haavoittuvuus suhteessa autonomiaan ja ontologiaan. Esittelemme seuraavaksi nämä teemakokonaisuudet havainnollistaen kutakin teemaa tarkastellun kirjallisuuden kautta. Lopuksi ehdotamme, millä tavalla haavoittuvuutta voisi hyödyntää teoreettisena käsitteenä silloin, kun tarkastellaan digitaalista subjektiutta ja läsnäoloa dataistuneessa mediassa.

\section{Datavalvonnan tuottamat haavoittuvuudet}

Datavalvonnan tematiikka on ollut datatutkimuksen keskiössä, minkä vuoksi ei ollut kovin yllättävää, että myös haavoittuvuutta on käsitelty tässä yhteydessä. Datavalvonnalla (dataveillance) voidaan tarkoittaa kaikkea henkilökohtaisesta tietovalvonnasta kokonaisten populaatioiden tietojen keräämisen ja seurannan käytäntöihin. Aihepiirin tutkimus löytää myös kaiken aikaa uusia alueita (Couldry ja Yun 2018.) Haavoittuvuus ilmenee tutkimuksessa kaksisuuntaisesti: yhtäältä se käsitetään populaatioiden ominaisuudeksi, jolloin tutkitaan populaatioon kohdistuvaa datavalvontaa (teknologiaa, käytäntöjä tai etiikkaa), tai sitten datafioidaan haavoittuvuutta (Schoemaker ym. 2021) ja kuvataan dataa, jonka avulla ihmisten todellinen haavoittuvuus on mahdollista osoittaa (social datafied sorting). Datafikaation ja datavalvonnan tuottama haavoittuvuus, yksityisyyden suojaamisen tarve siihen liittyvine teknologioineen sekä niiden käyttöön paikantuvat eriarvoisuudet voivat olla myös tutkimuksen lähtökohta (esim. Brough ja Martin 2020).

Ymmärretään haavoittuvuus sitten lähtökohtana tai tutkimuksen tuloksena, haavoittuvuuteen liittyvät datakokeilut ja niiden legitimointi ovat keskeisiä näkökulmia viime vuosien kriittisessä datatutkimuksessa. Kun esimerkiksi massiivisten tietojärjestelmien ja louhintaohjelmien mahdollistamien valvontatekniikoiden jatkuvaa yleistymistä tarkastellaan haavoittuvuuksien näkökulmasta, keskeiseksi näkökulmaksi nousee legitimaatio. Teoreettisimmissa artikkeleissa puretaan datafikaatioon liittyvien "humanitaaristen kokeilujen" etiikkaa 
ja seurauksia (mm. Vannini, Newell ja Gomez 2019; Ponzanesi 2019; Valentine 2019). Esimerkiksi biometriseen valvontaan liittyvä kontrolli ja eriarvoisuus nostetaan esille queer-tutkimuksen piirissä mutta myös pakolaisuuteen ja siirtolaisuuteen liittyvissä tutkimuksissa.

Maailman pakolaistilanne ja valtioiden välinen muuttoliike on nostanut tutkimuksen kohteeksi liikkuvien kansanryhmien lisääntyneen valvonnan ja tietojen keräämisen. Tämä näkyy eri puolilla maailmaa tehdyissä tapaustutkimuksissa, joissa pohditaan muun muassa haavoittuvassa asemassa olevien pakolaisten ja siirtolaisten yksityisyyden suojaamisen ongelmia ja heitä koskevan väestötiedon keräämisen ja hyödyntämisen etiikkaa. Artikkeleissa pohditaan esimerkiksi datapohjaisia seulontakäytäntöjä, erilaisten toimenpiteiden kohdentamiskäytäntöjä (esim. Vannini, Newell ja Gomez 2019) tai pakolaisten kokemuksia ja näkökulmia humanitaaristen järjestöjen ja viranomaisten hyödyntämiin digitaalisiin identifiointijärjestelmiin liittyen (Ajana 2020; Ponzanesi 2019; Baack 2015). Yhteistä on haavoittuvuuden ilmeneminen siinä, että datan keruun kohteilla näyttää olevan vähän tai minimaalisesti tietoa heitä koskevan datan käytöstä ja hallinnoimisesta.

Politiikan tutkimuksen alueella puolestaan nousee esille biometristen tietojen keräämiseen, rajavalvontaan ja kansalaisuuteen liittyviä kysymyksiä. Datavalvonnan muotojen ilmaantumisen on katsottu muokkaavan haavoittuvina pidettyjen ryhmien hallintaa. Tätä kuvataan ja haastetaan haavoittuvina pidettyjen ryhmien valvonnan muotoja koskevissa case-tutkimuksissa, joissa avataan esimerkiksi kodittomien, pakolaisten, vanhusten tai maahanmuuttajien tilanteita datavalvonnan kohteina. Tarkastelussa ovat myös big datan ja ennakoivan analytiikan käyttö ja niihin liittyvien riskien tunnistaminen erilaisten haavoittuvuuksien näkökulmasta. Tutkimuksissa käsitellään esimerkiksi sitä, kiinnitetäänkö algoritmien politiikkaa pohdittaessa tai algoritmeja eri tavoin hyödynnettäessä riittävästi huomiota siihen, miten haavoittuvat ryhmät näissä näkyvät. Big datan ja tekoälyn hyödyntäminen sosiaalisen valvonnan välineinä esimerkiksi julkishallinnossa avaa näkökulmia haavoittuvuuteen paitsi järjestelmien ja datan osalta myös väestöryhmiin liittyvinä haavoittuvuuksina - esimerkiksi tietojen, taitojen ja tietämisen puutteen mutta myös yksityisyyden suojan toteutumisen näkökulmasta. Kun esimerkiksi rikosoikeudellista ja sosiaalihuoltojärjestelmiin liittyvää tietoa yhdistetään, viranomaisvalvonta voi vahvistaa jo olemassa olevia haavoittuvuuksia tai synnyttää uusia (esim. Valentine 2019; Clarke, Parsell ja Lata 2020).

Datavalvonnan ja erilaisten ihmisiin ja ihmisryhmiin liittyvien haavoittuvuuksien yhteydet nousevat esille myös älykaupunkeja ja niiden valvontateknologiaa koskevassa tutkimuksessa. Älykaupunkisuunnittelun yhteydessä haavoittuvuudessa voi olla kyse siitä, että havaitaan syrjäytyneitä ryhmiä ja yhteisöjä koskevan datan puuttuminen tai sen keräämisen vaikeus sekä näiden ryhmien näkymättömyys dataprosesseissa (Heeks ja Satyarupa 2019). Jameson ja kumppanit (2019) puolestaan nostavat tutkimuksessaan esille älykaupunkeihin liittyvät konkreettiset huolet: oman ja muiden yksityisyyden, teknologian kanssa pärjäämisen sekä oman identiteetin hallinnan mahdollisuudet. Hatuka ja Toch (2017) toteavat, kuinka henkilökohtaisen datan tuottamiseen liittyvästä jatkuvasta näkyvillä ja valvonnan alla olemisesta on tullut älykaupunkisuunnittelussa normalisoitua, mikä aiheuttaa yksilötasolla haavoittuvuutta. Älykaupunkien algoritmeihin liittyvät eettiset kysymykset, kuten datakäytäntöjen ja päätöksenteon läpinäkyvyys tai tekoälyyn upotetut arvot, ovat haavoittuvuuksien näkökulmasta keskeisiä (Brauneis ja Goodman 2017). Haavoittuvuuden kokemus ja sen jakaminen voivat myös tarjota esimerkiksi marginalisoiduille ryhmille väylän vas- 
tustaa neutraaliksi miellettyä datahallintaa, joka ei todellisuudessa huomioi kaupungeissa elävien ihmisten moninaisuutta. Haavoittuvuuden, luottamuksen ja tästä syntyvän neuvottelun seurauksena inmisten on mahdollista kuvitella kaupunkiympäristöjä eri tavalla. (Keymolen ja Voorwinden 2020, 249.)

Haavoittuvuudesta on myös keskusteltu silloin, kun valvontakulttuuri ja sen kautta tuotettu tieto normalisoituu osaksi arkea (Hermida ja Hernández-Santaolalla 2020). Tässä yhteydessä on kiinnitetty huomiota datakäytäntöihin sitoutumisen emotionaalisiin ulottuvuuksiin (Keymolen ja Voorwinden 2020). Lupton ja Williamson (2017) ovat koonneet tutkimusta lasten asemasta ja oikeuksista datavalvonnan kohteina ja osoittavat, millaisia haavoittuvuuksia perheiden sisällä voi syntyä. Keymolenin ja Van der Hofin (2019) tutkimuksen perusteella taas älylelujen valmistajat, leikin tuottamaa dataa keräävät kolmannet osapuolet tai lasten vanhemmat voivat potentiaalisesti loukata lasta ja hänen oikeuksiaan, kuten oikeutta henkilötietojen suojaan tai yksityisyyteen. Etenkin etnografiset tutkimukset muistuttavat, että olisi tärkeää tutkia tietoisuutta datavalvonnasta ja sen kohteeksi joutumisesta osana arkisia käytäntöjä (Hermida ja Hernández-Santaolalla 2020).

Kun dataistumisen ja datafikaation myötä syntyviä haavoittuvuuksia tarkastellaan valvonnan ja kontrollin näkökulmasta, kiinnittyy huomio yhtäältä digitaalisten subjektien mahdollisuuksiin tulla tietoiseksi valvonnasta ja toisaalta datavalvonnan vaikutuksiin heidän toimijuuksiensa muotoutumisessa. Datavalvonnan ja haavoittuvuuksien näkökulmasta kiinnostavat eettiset keskustelut liittyvät valvonnan ja yksilöiden toiminnan ennakoinnin suhteisiin, eriarvoisuuskysymyksiin sekä datavalvonnan kokemuksellisiin ulottuvuuksiin.

\section{Data tietämisen tapana ja osallisuutena}

Haavoittuvuus tulee esille myös, kun dataa ja datakäytäntöjä lähestytään tietämisen, osaamisen ja osallisuuden näkökulmista. Esille nousevat kysymykset datan ja siitä tuotetun tiedon suhteesta ja sen aiheuttamasta haavoittuvuudesta. Tällöin puhutaan usein digitaalisesta ja dataan liittyvästä epätasa-arvosta. Dataan liittyvä epätasa-arvo kytkeytyy siihen, keillä on pääsy dataan, oikeus tulkita dataa (ja maailmaa sen avulla) tai mahdollisuus kontrolloida datavirtoja (Cinnamon 2019). Taustalla on ajatus, että epätasa-arvoiset mahdollisuudet tulkita ja hallita dataa aiheuttavat epätasa-arvoisesti jakautuvia yhteiskunnallisia toiminnan mahdollisuuksia ja siten haavoittuvuutta. Cinnamon (2019) kutsuu tätä tietämisen uudeksi digitaaliseksi kuiluksi (new digital divide of knowing). Kyse on myös valtasuhteista. Esimerkiksi Marlin-Bennettin (2016) mukaan digitaalisten subjektien tuottama ruumiillinen informaatio on aina kytköksissä konkreettisiin ihmiskehoihin, jolloin datan keräämiseen, siirtämiseen ja tulkintaan sisältyy valta-asetelmia. Hän nostaa pankkien kautta tehtyä rahanpesua tunnistavat algoritmit esimerkiksi tilanteesta, jossa dataa kerätään ja tulkitaan käyttäjiltä salassa. Keskeiseksi nousee kysymys, keillä on mahdollisuus päästä käsiksi dataan ja sitä kautta tulkita sitä tietona.

Teksteissä, joissa haavoittuvuutta lähestytään digitaalisen epätasa-arvon näkökulmista, pohditaan, keitä erilaiset digitaaliset laitteet ja data-alustat sekä niihin liittyvät politiikat hyödyttävät ja ketkä puolestaan suljetaan ulos. Ulossulkeminen liittyy usein puutteelliseen dataosaamiseen, kun esimerkiksi voimauttavaksi ja osallisuutta lisääväksi aiottu ICT- 
ratkaisu onkin suunniteltu vain valtaväestön tarpeita silmällä pitäen (Kamath 2018). Näissä tutkimuksissa haavoittuvuutta voidaan käyttää kuvailevana terminä tietyistä ihmisryhmistä, joiden elämäntilanteessa on taloudellisia, sosiaalisia tai toimintakykyyn liittyviä haasteita. Tällöin voidaan puhua myös datataidoista. Esimerkiksi Sourbati ja Behrendt (2020) nostavat esille iän merkityksen puutteellisten datataitojen yhteydessä. Helsperin ja Reisdorfin (2017) Ruotsissa ja Isossa-Britanniassa toteutetussa pitkittäistutkimuksessa taitojen ja pääsyn ohella myös motivaatioseikat tuottavat osaltaan digitaalista ekskluusiota. Ulossulkeminen ilmenee tällöin internetin käyttämättömyytenä. Haastavaksi tilanteen tekee se, että tutkimuksen perusteella ulossulkeminen on juurtunut aiempaa selvemmin haavoittuviksi nimettyihin ryhmiin, kuten matalasti koulutettuihin, eläkeläisiin, työttömiin tai sosiaalisesti vetäytyneisiin ihmisiin. Tutkijat luonnehtivatkin näitä ryhmiä “digitaaliseksi alaluokaksi” (Helsper ja Reisdorf 2017), eli sosioekonomisesti huonossa asemassa oleviksi, joille digitaalinen osallisuus ei välttämättä näyttäydy erityisen tavoiteltavana asiana.

Toisaalta digitaalisten alustojen kautta tuotetaan myös tilanteita, joissa yksilö pääsee osalliseksi alustasta, mutta hänestä kerättävän datan avulla kavennetaan hänen toimintamahdollisuuksiaan, esimerkiksi überisaationa tunnetun datalogiikan avulla. Tällöin jo entuudestaan heikossa asemassa olevaa työntekijää kontrolloidaan ja toimintamahdollisuuksia rajoitetaan digitaalisen järjestelmän ansaintalogiikan ehdoilla. Tämä aiheuttaa yksilötasolla haavoittuvuutta esimerkiksi niin, että vapaa-aikaa ei käytännössä ole. Usein tässä yhteydessä puhutaankin nykypäivän orjatyövoimasta, minkä nimenomaan dataan perustuvan alustan käyttö mahdollistaa (Firmino, de Vasconcelos Cardoso ja Evangelista 2019). Esineiden internet -palvelujen yhteydessä epätasa-arvo näkyy puolestaan esteellisenä pääsynä ja puuttuvina käyttötaitoina. Tällöin haavoittuvuus määrittyy epätasa-arvoisina osallistumisen mahdollisuuksina (van Deursen ym. 2021).

Haavoittuvuus digitaalisena epätasa-arvona ja erisuhtaisina osallistumisen mahdollisuuksina tulee esille myös erilaisilla hyvinvointiin liittyvillä data-alustoilla. Terveysteknologiaalustojen käytön yhteydessä on puhuttu niin sanotuista datafiteista eli yksilöistä, jotka ovat datataidollisesti kyvykkäitä ja sosioekonomisesti hyvässä asemassa (Charitsis 2019). Tällöin he pääsevät osallisiksi oman hyvinvointinsa hallinnasta. Vapaaehtoinen hoivaan tähtäävä oman datan kerääminen voi kuitenkin aiheuttaa haavoittuvuutta. Catlaw ja Sandberg (2018) tarkastelevat vapaaehtoista datan kerryttämistä quantified self -kulttuurissa. Itseä ja omaa hyvinvointia koskevaa dataa kerätään sekä oman olotilan parantamisen (self-care) että sen hallinnankin (self-government) nimissä. Tämä on oleellinen osa datafikaation kulttuuria ja sen infoliberaalia regiimiä. Ideaali infoliberaali kansalainen haluaa kerätä itseään koskevaa dataa ja osaa sitä myös hyödyntää. Tällainen datan kääntäminen toiminnaksi (Catlaw ja Sandberg 2018,17 ) voi lisätä itseymmärrystä ja toimii keskeisenä itsehoivan välineenä. Koska datan kerääminen erilaisten sovellusten avulla on kuitenkin usein hyvin pelillistettyä ja viihdyttävää, yksilö voi suostua datan kerryttämiseen myös vain huvin vuoksi, vaikka näin tuotettu data olisikin hänelle epäedullista. Haavoittuvuutta aiheuttaa omadatan keräämisen helppous ja arkipäiväistyminen, vaikka sitä alun perin olisi kerätty oman olotilan parantamisen nimissä.

Tutkimuksessa on nostettu esiin myös alustojen edellyttämä digitaalisen osallistumisen pakko (Loubere 2017) ja siihen liittyvä datalla hallinta. Tästä esimerkkinä on usein mainittu Kiinan sosiaalisen luototuksen järjestelmän suunnitelma, joka voi aiheuttaa epätasa-arvoa ja riistoa yksilön tasolla (emt.). Toisaalta nuoret aikuiset kokevat sisällön jakamisen sosiaa- 
lisessa mediassa niin tärkeäksi, että yksityisyyteen tai kontrolloimattomuuteen liittyneet huolet ovat toissijaisia (Hermida ja Hernández-Santaolalla 2020). Haavoittuvuus ei tule tällöin esiin niinkään kysymyksenä siitä, kuka pääsee osalliseksi erilaisista alustoista ja palveluista, vaan siinä, että näiden ulkopuolelle on oikeastaan mahdotonta asettua. Dataistuneen ympäristömme voidaan nähdä muokkaavan sosiaalisia maailmoja niin sanotuiksi datamaailmoiksi, joilla on omat tietämisen tapansa ja toimintamahdollisuutensa ja joihin osallistumiseksi tarvitaan moninaista datan lukutaitoa (Gray, Gerlitz ja Bounegru 2018).

Datafikaation aiheuttama haavoittuvuus voi siis olla toisaalta epätasa-arvoista pääsyä erilaisiin digitaalisiin palveluihin tai aineistoihin ja sitä kautta tuotettuun tietoon itsestämme mutta myös datavetoisen kulttuurin edellyttämää digitaalisen subjektin näkyvillä olemista. Tällöin haavoittuvuus kytkeytyy kiinnostavasti kysymykseen subjektin toimijuudesta ja siitä, onko haavoittuvuus lähtökohtaisesti jokaisen digitaalisen subjektin ominaisuus.

Haavoittuvuuden tematiikka suhteessa tietämiseen ja yksilön tietoon itsestään nouseekin esille, kun on tutkittu erilaisia hoivaan perustuvia sosiaalisia suhteita. Thornham (2019) esimerkiksi analysoi, kuinka hoivan sosioteknisissä systeemeissä yksilöstä muodostetaan datapohjainen versio. Kerätyn datan perusteella muodostetaan kuva yksilön tilanteesta, ja esimerkiksi terveydenhuollon toimenpiteet mitoitetaan tämän pohjalta. Tällöin vaikkapa oikeanlainen äitiys määritellään datapohjaisesti. Näin määritelty kuva ei kuitenkaan vastaa yksilön omaa elettyä kokemusta ja käsitystä omasta identiteetistä. Thornham käyttääkin tässä yhteydessä termiä algoritmiset haavoittuvuudet. Tällöin haavoittuvuutta aiheuttaa datapohjaisen ymmärryksen ja itseymmärryksen epäsuhta mutta myös yksilön hallintaan tähtäävä toiminta. (Thornham 2019.) Dataan perustuva valvonta on tässäkin tietämisen tavassa keskeinen toimintaperiaate. Tällöin puhutaan yksilöille koituvasta haavoittuvuudesta, mikä määrittyy kaventuvana yksilön itsemääräämisoikeutena.

Kun dataistumisesta koituvaa haavoittuvuutta tarkastellaan tietämisen ja osallisuuden näkökulmista, edeltävästä tutkimuksesta keskeiseksi teemaksi nousee toiminnan mahdollisuuksien ja oman kokemuksen epäsuhta. Voidaankin ajatella, että kun yksilön kokemus itsestä määrittyy tai määritellään enenevässä määrin datapohjaisesti, olisi syytä suunnata katse datasta generoidun tiedon "iholle tuleviin" vaikutuksiin. Tällöin arjen datakäytännöt ovat tärkeitä paikkoja, joissa esimerkiksi etnografisen tutkimusotteen avulla on mahdollista ymmärtää yksilöllisiä haavoittuvuuden kokemuksia. Toinen selkeä aihepiiri, jonka edeltävä tutkimuskirjallisuus nostaa esiin, on dataan ja data-alustoihin liittyvät ulossulkemisen kysymykset. Ne voidaan nähdä paitsi kysymyksenä siitä, keillä on mahdollisuus ja taidot päästä alustoille, myös siitä, onko alustojen ja datan ulkopuolelle mahdollista ylipäänsä asettua.

\section{Digitaalisten subjektien kategorisointi ja näkyvyyden säätely}

Haavoittuvuuden näkökulmasta kiinnostava nykytutkimuksen teemakokonaisuus liittyy siihen, millä tavoin haavoittuvuus on yhteydessä subjektien kategorisointiin ja heidän näkyvyytensä säätelyyn digitaalisten alustojen datavirroissa ja data-arkistoissa. Digitaalisten järjestelmien ja ohjelmistojen yhteydessä termiä haavoittuvuus käytetään yleensä kuvaamaan niihin sisältyviä virheitä, jotka aiheuttavat riskejä tietoturvallisuudelle (esim. Ruohonen, Hyrynsalmi ja Leppänen 2020). Nämä riskit voivat asettaa järjestelmien käyttäjät ja hei- 
dän tietonsa näkyviksi tahoille, joilla ei tulisi olla pääsyä tietoihin. Tässä osiossa keskitymme näkökulmiin, jotka täydentävät tätä tietoturva-aukkojen käyttäjille aiheuttamiin haittoihin keskittyvää aiempaa keskustelua.

Agostinhon ja kumppanien (2019) mukaan haavoittuvuudessa on kyse digitaaliseen arkistointiin liittyvästä tiedon epävarmuudesta ja epäjatkuvuudesta. He käyttävät ilmaisua datan liikkuvuus (data motility) kuvaamaan haavoittuvuutta, joka on seurausta yksilöiden tuottaman datan siirtymisestä yhä useammin heidän ulottumattomiinsa (emt. 2019, 437). Queer-tutkimuksessa on osoitettu, että data-arkistot eivät niinkään aseta valmiiksi haavoittuvina pidettyjä yksilöitä tai ihmisryhmiä tehostetun tarkkailun kohteeksi, vaan päinvastoin ne tekevät heidän olemassaolostaan eräällä tavalla mahdotonta. Schram (2019) esittää, että data-arkistot hävittävät kategorisoinnissaan herkästi ne subjektit, jotka eivät asetu tavanomaisten luokitusten sisälle. Toisaalta ongelmallista myös on, jos arkistot tietävät (tai väittävät tietävänsä) subjektien identiteettikategoriat ennen heidän omaa positioitumistaan tai jos dataluokitukset tunnustavat queer-käyttäjän osaksi LBGT-liikehdinnän yleistä kaanonia, joka tosiasiassa supistaa erilaisten queer-identiteettien kirjoa. (emt., 604-605.) Vastaavanlainen seuraus voi olla lentokenttien turvatarkastuksella, jossa virkailija luokittelee matkustajat läpivalaisussa joko naiseksi tai mieheksi, jolloin kone rekisteröi matkustajista sukupuolityypillisinä pidettyjä merkkejä. Jos algoritmivetoinen anatomian tunnistus ei kohtaa virkailijan tekemän luokituksen kanssa, kehot voidaan määritellä turvallisuusuhaksi. (Shabbar 2018, 209-210.)

Sukupuolen näkökulmasta marginaalisiin ryhmiin kohdistuu siis kahdenlaista haavoittuvuutta. Yhtäältä heidän datajälkiensä käsittely mitätöi tai pelkistää eri identiteettejä normatiivisiksi kategorioiksi. Toisaalta queer-subjekteja pyritään samalla tekemään tai pakottamaan näkyviksi, millä voi olla tuhoisia seurauksia heidän elämillensä. Tutkimusartikkeleissa seksityöläiset esiintyvät vastaavanlaisena ryhmänä, joille on voinut koitua merkittäviä haittoja datavalvonnan tuottamasta näkyvyydestä (Jameson, Richter ja Taylor 2019, 1478-1479). Triggs ja kumppanit (2019) kuitenkin tähdentävät, että haavoittuvuus ja voimaantuminen kulkevat usein käsi kädessä digitaalisessa queer-ontologiassa. Queer-yksilöt joutuvat kontrolloimaan sitä, etteivät sovellukset tai heidän seuraamansa sivustot tuo julki kulttuurisesti stigmatisoitua identiteettiä. Samalla nimimerkein käytetyt keskustelualustat, kuten Reddit, tarjoavat marginalisoiduille yhteisöille mahdollisuuden olemassaololle ja keskinäiselle vuorovaikutukselle.

Digitaalisia subjekteja koskevan informaation näkyvyyttä voidaan lähestyä myös toisesta näkökulmasta. Monet digitaaliset alustat tuottavat tietyille ihmisryhmille paineita jakaa heitä koskevaa henkilökohtaista informaatiota. Esimerkiksi hi-virusta (hiv) kantaville ihmisille on asetettu joko laillisia tai moraalisia velvoitteita kertoa statuksestaan seksikumppaneilleen. Digitaalisen median alustat, kuten eri seuranhakupalvelut, ovat hankaloittaneet hiv-positiivisten asemaa, koska eettiset normit ovat alkaneet suosia informaation julkistamista myös näillä alustoilla. MacAulay (2019, 253-255) luonnehtii tilannetta digitaaliseksi haavoittuvuudeksi. Hiv-positiivisuudesta kertominen voi asettaa subjektit stigmatisoinnin ja häirinnän kohteeksi. Toisaalta MacAulay osoittaa, että sairaudesta kertominen seksikumppanille ei näyttäydy enää riittävän vahvana todisteena oikeudessa, jos käyttäjät eivät ole tuottaneet hiv-positiivisuudesta digitaalista jälkeä seuranhakualustalle. Vaikka tutkijat viittaavat haavoittuvuudella usein tutkittavien kokemukseen tarkkailusta ja tietoturvahuolista, haavoittuvuutena voidaan pitää siis tilannetta, jossa yksilöt joutuvat valitsemaan kahden heille epäsuotuisan vaihtoehdon välillä. 
Lawson (2018) puolestaan yhdistää case-tutkimuksessaan digitaalisten alustojen haavoittuvuuden ja mustien naisten haavoittuvuuden. Hän toteaa digitaalisen alustojen, kuten Twitterin, altistavan erityisesti mustat naissubjektit rasistisille ja naisvihamielisille hyökkäyksille ja nostaa esiin alustojen omistajien roolin siinä, millaista haavoittuvuutta verkkovihatapauksissa digitaalisiin subjekteihin voi kohdistua. Lawsonin tutkimus paikantuu osaksi verkkovihaan ja -misogyniaan kohdistuvaa feminististä tutkimusta (ks. esim. Ging ja Siapera 2018).

Datafikaation queer-tutkimuksen ja feministisen tutkimuksen viitekehykseen paikantuvat tutkimukset osoittavat, että haavoittuvuus nivoutuu näissä teksteissä selvästi digitaalisten subjektien identiteettiin, vaikka tekstit eivät usein purakaan auki haavoittuvuuden käsitettä. Sen sijaan haavoittuvuutta käytetään viittaamaan yleisesti haitallisiin kokemuksiin. Tutkimusten pohjalta voidaan kuitenkin ajatella, että institutionaalisten datakäytäntöjen pyrkimykset tehdä selkoa maailmasta tietyistä lähtökohdista käsin epäonnistuvat tehtävässään siksi, että ne eivät huomioi sosiaalisen elämän monimuotoisuutta. Tästä seuraa erilaisia haavoittuvuuksia: queer-subjektit voidaan joko dataluokitusten näkökulmasta kadottaa tai heidät voidaan asettaa tehostetun valvonnan kohteeksi. Vastaavasti feministiset subjektit joutuvat tasapainoilemaan oman näkyvyytensä ja usein tätä seuraavan verkkovihan välillä. Nämä haavoittuvuudet osoittavat, että kaikkia datafikaation yksilöllisiä seurauksia ei ole mahdollista tarkastella esimerkiksi tunnepuheina siitä, mitä subjektit ajattelevat datan keräämisestä ja prosessoinnista. Kysymys on sen sijaan laajemmin elämästä ja mahdollisuudesta elämään.

\section{Haavoittuvuus suhteessa autonomiaan ja ontologiaan}

Datafikaatiota koskevassa tutkimuskirjallisuudessa haavoittuvuus kytkeytyy myös siihen, miten digitaalisten subjektien autonomia ymmärretään tai miten datan kerääminen ja kierto kaventavat tai toisinaan myös tukevat autonomiaa. Usein tarkastellaan sitä, miten digitaaliset alustat ja sovellukset vaikuttavat subjektien autonomiaan tai olemassaolon ehtoihin tai millaista valtaa niillä on subjektien toimijuuteen (esim. Keymolen ja Van der Hof 2019; Goriunova 2019). Joissain tutkimuksissa haavoittuvuus voidaan ymmärtää kaikkien käyttäjien luontaiseksi olotilaksi, jolloin tarkastelussa painottuvat digitaaliseen olemassaoloon ja suhteisiin tai ontologiaan liittyvät kysymykset. Digitaalisten subjektien ontologinen haavoittuvuus liittyy avoimuuteen ja datan tallentumiseen verkottuneessa maailmassa, jossa subjektien kohtaamiset ja läsnäolot mahdollistavat yhteyden toisiin ja altistumisen toisten toiminnalle (Miller 2019). Tällöin kyse on autonomian ja luottamuksen ulottuvuuksista subjektien välisessä vuorovaikutuksessa, jonka kiinteä osa digitaaliset alustat ja algoritmit ovat. Haavoittuvuus ontologisena kysymyksenä nostaakin esiin digitaalisten subjektien suhteet toisiinsa erilaisissa verkkoympäristöissä.

Yksilöiden lähtökohtaiseen haavoittuvuuteen internetissä suhtaudutaan tutkimuksissa eri tavoin. Miller (emt., 172-173) katsoo, että subjektien erityinen ontologinen haavoittuvuus verkkovuorovaikutuksessa juontaa yhtäältä siitä, että digitaalisilla alustoilla ollaan fyysisesti etäällä toisista, jolloin voidaan olla avoimen luottavaisia ja saatetaan omaksua ajatus ruumiillisesta haavoittumattomuudesta. Toisaalta haavoittuvuus kiinnittyy jatkuvaan ja arkistoituvaan läsnäoloon erilaisissa verkostoissa ja tietokannoissa, mikä tekee toiminnasta 
jäljitettävää. Feministisen ontologian piirissä taas on pohdittu ruumista eksistentiaalisena kysymyksenä, johon digitaalisen median kontekstissa keskeisenä tunnerakenteena liittyy haavoittuvuus. Digitaalisessa olemassaolossa subjektit tulevat "heitetyiksi” erityiseen paikantuneeseen kontekstiin, johon eivät ole itse voineet vaikuttaa ja joka voi muuttua varoittamatta. Schwartzin $(2019,8)$ mukaan tämä johtaa haavoittuvuuteen, koska se osoittaa yksilöllisen kontrollin rajat. Feministisen ontologian ei tule hänen mukaansa vain tunnistaa teknologian ja kulttuurin suhteeseen paikantuvaa haavoittuvuutta vaan harjoittaa sen suhteen hoivan etiikkaa. Schwartzille haavoittuvuus paikantuu elettyihin ruumiillisiin ja intersektionaalisiin olosuhteisiin digitaalisissa tiloissa.

Haavoittuvuudessa ei ole välttämättä kyse heikkoudesta, vaan affektiivisesta latauksesta, joka kytkeytyy toimijuuteen ja äänen antamiseen eri toimijoille (Koivunen, Kyrölä ja Ryberg 2018). Chun (2016a) katsoo, että digitaaliseen kulttuuriin liittyvä tunnustuksellisuus ja yksityisiksi miellettyjen asioiden tuominen julkisille areenoille on tapa kurottautua kohti yhteisöä. Tällöin yksilöllisestä haavoittuvuudesta tehdään jaettua. Esimerkiksi Mäkisen (2020) kaupallisista lähtökohdista toimivia äitiysbloggareita koskevassa tutkimuksessa oman perhe-elämän jakaminen ja altistuminen seuraajien taholta tapahtuvalle kiusaamiselle ymmärretään haavoittuvuudeksi. Tässä kontekstissa bloggarit ikään kuin myyvät haavoittuvuutta osana työtään sellaisessa digitaalisessa ympäristössä, jossa datan kierron kontrollointi on lähes mahdotonta.

Chunin (2016a) mukaan tulee tavoitella sellaista verkottunutta julkisuutta, jossa voi olla haavoittuva ilman, että joutuu hyökkäyksen tai vihan kohteeksi. Tällöin haavoittuvuus ymmärretään digitaalisten subjektien suuntautumiseksi kohti toisia, mutta ei niinkään suojelua vaativaksi olotilaksi, vaan digitaaliseen subjektiuteen liittyväksi oikeudeksi. Fotopoulou (2016, 19-22) hyödyntää biodigitaalisen haavoittuvuuden käsitettä kuvatessaan ontologiaa, joka on läsnä feminististen subjektien muotoutumisessa digitaalisissa tiloissa. Hänelle kysymys subjektien toimijuudesta on erottamaton digitaalisten teknologioiden toimijuudesta, jotka vaikuttavat toinen toisiinsa. Esimerkiksi feministeihin kohdistuvaa häirintää ja tästä syntyvää vastaliikehdintää voidaan käyttää havainnollistamaan digitaalista toimijuutta, joka kiinnittyy haavoittuvuuden ja voimaantumisen rajapinnalle.

Kun puhutaan subjekteista, oikeuksista ja toimijuudesta datakäytännöissä, huomio on yleensä aikuisissa, jotka muodostavat normatiivisen digitaalisen subjektin. Livingstone ja Third (2017) toteavat, että lapsi näyttäytyy dataistuneen median puhetavoissa peilinä, joka uusintaa normatiivisen aikuissubjektin legitimiteettiä digitaalisissa ympäristöissä. Internetin hallinnallisista ulottuvuuksista puhuttaessa lapset voidaan ohittaa kokonaan tai heihin viitataan ohimenevästi suojelua tarvitsevina haavoittuvina subjekteina. Livingstone ja Third (2017) ehdottavat, että digitaalisissa ympäristöissä lapsen osallistumisen oikeuksien tulisi olla läsnä yhtä vahvasti kuin suojelemisen tarpeen. Vastaavasti vammaisten lasten digitaalisia toimijuuksia ja oikeuksia tutkittaessa on tuotu esiin, että heidän haavoittuvuutensa korostamisen sijaan tulisi tarkastella, kuinka moniulotteisesti digitaaliset alustat ja digitaalisen kommunikaation muodot kietoutuvat vammaisuuden sosiaaliseen muovautumiseen ja vammaisten lasten kulttuuriseen kansalaisuuteen (Alper ja Goggin 2017). Digitaalisten subjektien olemassaolon tai autonomian näkökulmasta haavoittuvuus voidaan ymmärtää tuottavaksi käsitteeksi, johon liittyy mahdollisuus artikuloida uudenlaisia subjektiviteetteja ja kulttuurista kansalaisuutta. 
Ontologiaan ja autonomiaan liittyviä haavoittuvuuksia tarkastellaan myös kuolemaa tai kuolemista koskevissa tutkimuksissa. Näissä haavoittuvuutta käsitellään toisistaan eroavista näkökulmista. Osalle tutkijoista haavoittuvuus on tiukasti sidoksissa voimaantumiseen, jolloin haavoittuvuutta tulee pitää "ontologisesti annettuna" (Lagerkvist ja Andersson 2017, 552-555). Lagerkvistin ja Anderssonin (emt.) mukaan läheisensä menettäneiden virtuaaliset tukiryhmät ja toisaalta kuolemansairaiden ylläpitämät blogialustat ilmentävät jaettua haavoittuvuutta, jonka avulla kirjoittajat havainnollistavat käyttäjien suhdetta toisiinsa ja maailmaan laajemmin. Muuttuvassa, kuolemaa, ahdinkoa ja katastrofeja näkyväksi tekevässä mediaympäristössä olemme toisin sanoen kaikki sidoksissa toisiimme ja samalla muuttuneet subjekteina kenties aiempaa herkemmiksi. Tästä kirjoittajien mukaan seuraa myös haavoittuvuuden voimaannuttava puoli.

Tutkijat suhtautuvat haavoittuvuuden ja kuoleman kysymyksiin myös kriittisesti. Kuoleman läsnäolo ja näkyvyys voi tuottaa haavoittuvuuksia kriisitapahtumien paikallaolijoille, heidän läheisilleen ja myös muille internetin käyttäjille. Hjorth ja Cumiskey (2018) huomauttavat, että niin tapaturmat kuin väkivallanteot tallentuvat nykyään helposti älypuhelimille, jolloin kriiseistä selvinneet - sekä myös vainajat - saattavat tallettaa kuolemaan johtaneita tilanteita digitaaliseen mediaan. Häiritsevä materiaali myös leviää nopeasti. Toisaalta kuvasto voi tarjota menehtyneiden ihmisten läheisille mahdollisuuden olla rakkaitaan lähellä heidän viimeisinä hetkinään. Digitaalisessa mediassa kuolemaa on pidetty vaikeana kysymyksenä myös kriisitilanteiden ulkopuolella, koska menehtyneiden käyttäjien tileillä voi olla heidän omaisilleen tunnearvoa. Alustat kuitenkin vaikuttavat käyttäjien tapoihin ilmaista ja kuvata itseään, ja ne myös asettavat ehtoja datan tallennukselle. Alustoilla on siis käyttäjätileihin ja niihin liittyvään dataan nähden valtaa, minkä suhteen kysymys omaisten pääsystä menehtyneen käyttäjäprofiiliin ja kuvavirtaan ei ole vain juridinen vaan myös moraalinen. (Kreiczer-Levy ja Donyets-Kedar 2019.)

Autonomiaan ja ontologiaan liittyvät kokemukset haavoittuvuudesta tekevät usein näkyväksi valta-asemia ja oikeuksia tai eriarvoisuutta tuottavia institutionaalisia käytäntöjä. Digitaalisten subjektien ontologisia kysymyksiä lähestyvissä teksteissä haavoittuvuutta analysoidaan yleensä teoreettisemmin kuin muussa datafikaatiotutkimuksessa. Etenkin feministiselle datatutkimukselle haavoittuvuus näyttäytyy teoreettisena käsitteenä, jota problematisoidaan monitahoisesti subjektien olemassaoloon ja toimijuuden ehtoihin keskittyen.

\section{Johtopäätökset}

Kartoittamamme tutkimuskirjallisuuden perusteella datan kerääminen ja digitaaliset toimintaympäristöt tuottavat haavoittuvuutta, joka ilmenee niin subjektien muotoutumisessa, näkyvyydessä, kategorisoinnissa, osallisuudessa, suhteissa (dataan ja toisiin subjekteihin) kuin digitaalisen olemassaolon ontologisessa luonteessa. Yhteiskunnallinen ilmapiiri ja tilanne näkyvät läpikäytyjen julkaisujen teemoissa. Esimerkiksi vuoden 2015 pakolaistilanteeseen liittyen julkaisujen joukossa on useita empiirisiä analyysejä pakolaisten asemasta datavirroissa ja datavalvonnan kohteina. Lähivuosien haavoittuvuustekstien yksi näkyvä teema on todennäköisesti koronaviruspandemia ja erilaiset rajoitustoimiin ja virusjäljittämiseen liittyvät datakäytännöt. 
Kokemuksellista tietoa arkipäivän datasuhteisiin liittyvästä haavoittuvuudesta näyttää vielä tutkimuksesta puuttuvan. Sitä puuttuu paitsi digitaalisen osallisuuden kannalta haavoittuviksi määritellyistä ihmisryhmistä myös dataistuneen median keskiössä olevista aktiivikäyttäjistä, joita ei lähtökohtaisesti pidetä haavoittuvina. Jonkin verran sanastoa yksilöiden tunteista suhteessa datafikaatioon ja sen seurauksiin löytyy, mutta se ei välttämättä tavoita digitaalisten subjektien moniulotteista suhdetta datafikaatioon ja siihen liittyviin haavoittuvuuden ulottuvuuksiin.

Datafikaation kontekstissa on todennettavissa joitain aukkoja ja lähestymistapoja, joista kaivattaisiin lisää tutkimusta. Ensiksi datafikaation haavoittuvuuksia käsittelevissä tutkimuksissa tarvittaisiin tarkempaa haavoittuvuuden määrittelyä ja kriittistä teoreettista tarkastelua - aivan kuten on todettu muillakin tutkimusaloilla (esim. Virokannas, Liuski ja Kuronen 2020). Haavoittuvuustutkimusta rasittaa se, että varsin usein käsite jätetään kokonaan määrittelemättä. Mikäli haavoittuvuus ymmärretään heikkoudeksi, riippuvuudeksi tai resurssien puutteeksi, tästä helposti seuraa, että haavoittuviksi kutsuttujen yksilöiden ja ihmisryhmien toimijuuden mahdollisuuksia kavennetaan tai uusinnetaan heihin liittyvää stereotyyppistä ajattelua (Mackenzie, Rogers ja Dodds 2014, 6). Haavoittuvaksi nimeämisen seurauksia on syytä tarkastella ja teoretisoida nimenomaan datafikaation kontekstissa, sillä datafikaatio tuottaa suhteita, joissa haavoittuvuus voi toteutua erityisin tavoin.

Toiseksi luentamme haavoittuvuuskirjallisuudesta toi esiin, että datan jättämien jälkien tuottama haavoittuvuus on usein hahmottumatonta. Lisäksi se voi kiinnittyä digitaalisilla alustoilla toimintaan, joka koetaan itselle mieluisaksi, tärkeäksi tai voimaannuttavaksi. Digitaalinen haavoittuvuus ei siis ole yksinomaan negatiivisten tunteiden ja kokemusten kenttää. Kun esimerkiksi itse tuotetut datajäljet kietoutuvat näkymättömiin jälkiin, joiden kerääjistä tai käyttötavoista ei ole varmuutta, tuottaa se haavoittuvuuden ja voimaantumisen välisen ristiriidan. Vastaavanlaista ristivetoa liittyy tilanteeseen, jossa alustat tarjoavat marginaalissa eläville ihmisille potentiaalisesti turvallisen tilan mutta samalla velvoittavat paljastamaan sensitiivisiä tietoja muille käyttäjille (MacAulay 2019). Pelkästään datan käsittelijöille näkyvät datajäljet voivat haavoittaa subjektia ja aiheuttaa huolen, pelon ja levottomuuden kokemuksia.

Kolmanneksi datafikaatiotutkimuksen jännitteinen tematiikka liittyy kysymykseen subjektin vapaaehtoisuudesta näkyä ja osallistua. Jos datavetoiseen kulttuuriin osallistuminen edellyttää aina asettumista näkyvän digitaalisen subjektin asemaan, se voidaan yksilötasolla kokea ongelmaksi tai osallistumisen esteeksi. Tämänkaltainen pakotettu näkyvyys on omiaan tuottamaan haavoittuvuutta. Neljäs lisätutkimusta kaipaava kysymyksenasettelu liittyy siihen, miten digitaalisen läsnäolon muuttuvuuteen ja ennakoimattomuuteen sisältyy lähtökohtaisesti aina haavoittuvuutta. Haavoittuvuuden kokemukset digitaalisilla alustoilla eivät ole irrallisia yksilöiden ja ryhmien eriarvoisista asemista. Digitaaliset alustat eivät yksioikoisesti lisää lähtökohtaisesti haavoittuvina pidettyjen yksilöiden eriarvoisuutta eikä haavoittuvuus automaattisesti aktualisoidu keskimääräistä haavoittuvammassa asemassa olevan yksilön digitaalisessa toimijuudessa. Digitaalisessa haavoittuvuudessa on kyse monimutkaisista diskursiivisista ja ruumiillisista kerrostumista, hetkellisyydestä ja datavetoisista suhteista, joiden kontekstisidonnainen tarkastelu on keskeistä.

Esitämme, että haavoittuvuuskäsitettä kannattaisi hyödyntää nykyistä enemmän mediatutkimuksessa ja kriittisessä datatutkimuksessa. Haavoittuvuuden käsite soveltuu teoreet- 
tiseksi työkaluksi, jonka avulla voidaan tutkia datafikaatioon liittyviä mahdollisuuksia ja toiminnan ehtoja. Käsitteellä on mahdollista tavoittaa monitahoisesti digitaalisten subjektien kokemuksellisuutta ja toimijuutta suhteessa alustoihin, sovelluksiin ja toisiin subjekteihin. Läheskään aina haavoittuvuus ei ole datasuhteisiin liittyvän kokemuksellisuuden määräävä tekijä, vaan se kietoutuu osaksi tilanteisia, materiaalisia ja sosiaalisia käytäntöjä ja kohtaamisia.

Nähdäksemme relevantti suunta olisi lähteä pohtimaan, mitä annettavaa haavoittuvuudella on, jos sitä lähestytään tunnerakenteena ja eettisenä resurssina datasuhteissa. Erinn Gilsonin haavoittuvuuden teoretisoinnin pohjalta ehdotamme, että datafikaation tutkimuksessa voitaisiin luopua sellaisesta yksinkertaistavasta lähtökohdasta, jossa haavoittumattomuus näyttäytyy vääjäämättä tavoiteltavana ja haavoittuvuus ei-toivottuna. Tämän sijaan haavoittuvuutta voitaisiin lähestyä kokemuksellisuutena, johon liittyy erehtyväisyys, muuttuvuus, ennakoimattomuus, kontrolloimattomuus ja levottomuus. (Gilson 2014, 3-6.) Tällöin kyetään tarkastelemaan, millä tavoin nämä haavoittuvuuden ulottuvuudet hahmotetaan ja miten niiden kanssa yritetään tulla toimeen suhteessa dataan, datajälkiin ja toisiin subjekteihin. Tämä ei kuitenkaan tarkoita, että yksilöiden haavoittuvuuksien kokemuksellisuuden tarkastelussa ohitettaisiin eroihin kiinnittyvät positiot ja niihin sisältyvät eriarvoisuuden ja epätasa-arvon muodot.

Kokemuksellisen haavoittuvuuden kompleksisuutta ja monimuotoisuutta on mielekästä lähestyä tunnerakenteena (ks. myös Schwartz 2019). Avoimuus ja kyky kuvitella, tuntea ja nähdä päästämällä irti normatiivisista tulkinnoista tai vakiintuneista ymmärtämisen tavoista on osa haavoittuvuuden dynamiikkaa (Gilson 2014, 3). Tällöin etualalle nostetaan subjektien avoimuus ja tietoinen alttius tulla liikutetuksi olosuhteissa, joita he eivät välttämättä voi kontrolloida. Tutkimuksessa olisi paikallaan kysyä esimerkiksi, millaisissa dataistuneen arjen tilanteissa subjektit esittävät maailmassa olemiselleen keskeisiä kysymyksiä. Miten ja milloin he avautuvat, saadakseen ja antaakseen tunnustusta, tai kaipaavat keinoja tuntea toisin? Haavoittuvuudessa tunnerakenteena on kyse ensinnäkin siitä, miten subjektit tulevat liikutetuiksi ja miten he tulkitsevat liikuttuneisuuttaan digitaalisissa kohtaamisissa. Näin se lähestyy sellaista datafikaation tutkimusta, joka painottaa affektiivisten intensiteettien keskeisyyttä yksilöiden datasuhteissa ja datan prosessuaalisuutta eletyissä kokemuksissa (esim. Sumartojo ym. 2016). Toiseksi haavoittuvuuden tunnerakenne ohjaa kysymykseen siitä, miten subjektit todistavat ja arvioivat toisten haavoittuvuutta digitaalisilla alustoilla. Kolmanneksi se nostaa esiin kysymyksen, miten digitaaliset subjektit reagoivat tilanteisiin, joissa kokevat epävarmuutta, levottomuutta, epämukavuutta tai kontrollin menettämisen pelkoa - olipa kyse sitten neuvottelusta algoritmien, alustojen toimintalogiikan tai toisten jättämien datajälkien kanssa.

Kuvaamamme haavoittuvuus tunnerakenteena tulee lähelle datatutkimuksessa creepinesstermillä kutsuttua tuntemusta siitä, että omaa dataa kohdellaan väärin tai odotusten vastaisesti (Shklovski ym. 2014). Creepiness kuitenkin kuvaa yksilön emotionaalista reaktiota datan keruun näkymättömään puoleen, kun taas haavoittuvuuden kokemuksessa digitaaliset subjektit eivät reagoi pelkästään dataan, vaan asettuvat datasuhteissaan alttiiksi niin toisille digitaalisille subjekteille kuin toisten subjektien haavoittuvuuden todistamiselle sekä alustojen toimintalogiikalle. Tällöin haavoittuvuus on uudenlaista suhteisuutta, jota dataistuminen synnyttää. Kuten Mackenzie (2014) esittää, passiiviseksi ja suojelua kaipaavaksi mielletyn haavoittuvan subjektin ja autonomisen toimijuuden vastakkainasettelun sijaan tulisi suosia 
sellaista näkökulmaa haavoittuvuuteen, joka edistää haavoittuvuutta kokevien yksilöiden kykyä autonomiaan ja tasa-arvoiseen osallisuuteen. Haavoittuvuus määrittyy eritasoisissa yksilöllisissä ja institutionaalisissa konteksteissa ja niihin liittyvissä kytköksissä, suhteisuutena. Myös dataistuneen kulttuurin raameissa suhteisuus on se, mikä haavoittuvuutta tuottaa. Siksi yksilölliset tunnerakenteet suhteiden ilmentyminä ovat niitä pisteitä, joissa on mahdollista tunnistaa paitsi rakenteellista ja alistavaa haavoittuvuuden kokemusta myös digitaaliseen subjektiuteen liittyvää ontologista haavoittuvuutta, joka voi olla myös niin sanottua hyvää elämää tuottavia suhteita.

Toiseksi ehdotamme, että haavoittuvuus voitaisiin ymmärtää eettisenä suuntautumisena ja resurssina (Gilson 2014, 5), jossa keskeistä on subjektien kokema haavoittuvuus suhteessa dataan, algoritmeihin ja digitaaliseen infrastruktuuriin. Tällöin painottuu subjektien riippuvuus datasta ja alustoista, mikä altistaa heidät erilaisille harmeille ja haitoille mutta myös eettiselle reagointikyvylle. Tässä yhteydessä haavoittuvuus voidaan tulkita signaaliksi, joka herättää yksilöt pohtimaan erilaisia moraalisia velvoitteitaan tai sitoumuksiaan (Mackenzie, Rogers ja Dodds 2014, 10). Datavetoisen kulttuurin tutkimuksessa olisi nähdäksemme tarpeellista tarkastella nykyistä monisyisemmin, millaisia eettisiä kysymyksiä ja ongelmia haavoittuvuuteen liittyy alustakohtaisissa konteksteissa, vaikka niihin ei useinkaan ole löydettävissä yksiselitteisiä vastauksia. Huomion tulisi olla yhtäältä siinä, miten yksilöt digitaalisilla alustoilla toimiessaan tunnistavat ja kokevat oman haavoittuvuutensa ja toisten haavoittuvuuden, ja toisaalta siinä, millaisia eettisiä lähestymistapoja ja moraalisia velvollisuuksia he havaitsemaansa haavoittuvuuteen liittävät.

Haavoittuvuuden käsitteen hyödyntäminen olisi paikallaan etenkin silloin, kun tutkitaan sellaisia datavetoisen kulttuurin olosuhteita ja seurauksia, jotka eivät ilmennä selkeää kahtiajakoa datataloudesta hyötyvien ja datatalouden marginalisoimien yksilöiden välillä tai datavalvontaa harjoittavien ja valvottujen välillä. Haavoittuvuus datafikaation konteksteissa on ennemmin erilaisiin suhteisiin ja välitiloihin paikantuvaa monitulkintaisuutta ja kompleksisuutta, joka toimii mahdollisuutena rakentaa eettisiä suhteita toisiin. Tutkimusta haavoittuvuudesta kaivattaisiin erilaisten inmisryhmien tavoista neuvotella data-arkeaan, kyseenalaistaa datan keruun ja sen hyödyntämisen itsestäänselvyyttä sekä siitä, millaisena datasuhteiden tilanteisena tunnerakenteena tai eettisenä reagointina haavoittuvuus heille näyttäytyy. Kyse on siitä, mitä inmiset ajattelevat omasta ja toisten haavoittuvuudesta erilaisilla digitaalisilla alustoilla ja erilaisissa kulttuurisissa yhteisöissä. Haavoittuvuuden tutkimus datafikaation kontekstissa avaa näin mahdollisuuden kuvitella ja siten myös toivottavasti muokata monimuotoisempaa dataistunutta toimijuutta. Koska haavoittuvuus on keskeinen digitaalisen läsnäolon ja kokemuksellisuuden ulottuvuus, toivoisimme, että siihen liittyvä monimutkainen dynamiikka löytäisi nykyistä enemmän suomenkieliseen media- ja datatutkimukseen.

\section{Jälkisanat}

Kirjoittajien listaamisessa on käytetty aakkosjärjestystä, koska kaikki kirjoittajat ovat osallistuneet tasapuolisesti tutkimus- ja kirjoitusprosessiin. Tehty tutkimus on osa Strategisen tutkimuksen neuvoston rahoittamaa hanketta Intiimiys datavetoisessa kulttuurissa (projektinumerot 327392 ja 327394). 


\section{Kirjallisuus}

Agostinho, Daniela, Catherine D'Ignazio, Annie Ring, Nanna Bonde Thylstrup ja Kristin Veel. 2019. “Uncertain Archives: Approaching the Unknowns, Errors and Vulnerabilities of Big Data through Cultural Theories of the Archive." Surveillance and Society 17 (3/4): 422-441. https://doi.org/10.24908/ss.v17i3/4.12330.

Ajana, Bhitaj. 2020. "Digital Biopolitics, Humanitarianism and the Datafication of Refugees." Teoksessa Refugee Imaginaries: Research Across the Humanities, toimittaneet Emma Cox, Sam Durrant, David Farrier, Lyndsay Stonebridge ja Agnes Woolley, 463-479. Edinburgh: Edinburgh University Press.

Alper, Meryl ja Gerard Goggin. 2017. "Digital technology and rights in the lives of children with disabilities." New Media Q Society 19 (5): 726-740. https://doi.org/10.1177/1461444816686323.

Andrejevic, Mark. 2019. Automating Surveillance. Surveillance Q Society 17 (1/2): 7-13. https://doi.org/10.24908/ss.v17i1/2.12930.

Baack, Stefan. 2015. "Datafication and empowerment: How the open data movement re-articulates notions of democracy, participation, and journalism." Big Data Q Society 2 (2): 1-11. https://doi.org/10.1177/2053951715594634.

Barassi, Veronica. 2019. "Datafied citizens in the age of coerced digital participation." Sociological Research Online 24 (3): 414-429. https://doi.org/10.1177/1360780419857734.

Barnes, Susan B. 2006. "A privacy paradox: Social networking in the United States." First Monday 11 (9). https://doi.org/10.5210/fm.v11ig.1394.

Brauneis, Robert ja Ellen Goodman 2017. "Algorithmic Transparency for the Smart City." Yale Journal of Law and Technology 103 (20), 107-176.

Brough, Aaron R. ja Kelly D. Martin. 2020. "Critical roles of knowledge and motivation in privacy research." Current Opinion in Psychology 31: 11-15. https://doi.org/10.1016/j.copsyc.2019.06.021.

Catlaw, Thomas J. ja Billie Sandberg. 2018. "The quantified self and the evolution of neoliberal self-government: An exploratory qualitative study." Administrative Theory Q Praxis 40 (1): 3-22. https://doi.org/10.1080/10841806.2017.1420743.

Charitsis, Vassilis. 2019. "Survival of the (data) fit: Self-surveillance, corporate wellness, and the platformization of healthcare." Surveillance Q Society 17 (1/2): 139-144. https://doi.org/10.24908/ss.v17i1/2.12942.

Corple, Danielle ja Jasmine Linabary. 2020. "From data points to people: feminist situated ethics in online big data research." International Journal of Social Research Methodology 23 (2): 155-168. https://doi.org/10.1080/13645579.2019.1649832.

Couldry, Nick ja Andreas Hepp. 2017. The mediated construction of reality. Cambridge: Polity.

Chun, Wendy Hui Kyong. 2016a. Updating to Remain the Same: Habitual New Media. Cambridge, Massachusetts: The MIT Press.

Chun, Wendy Hui Kyong. 2016b. "Big Data as Drama." ELH 83 (2): 363-382.

Cinnamon, Jonathan. 2019. "Data inequalities and why they matter for development." Information Technology for Development 26 (2): 214-233. https://doi.org/10.1080/02681102.2019.1650244.

Clarke, Andrew, Cameron Parsell ja Lutfun Nahar Lata. 2020. "Surveilling the marginalised: How manual, embodied and territorialised surveillance persists in the age of 'dataveillance'." The Sociological Review 69 (2): 396-413. https://doi.org/10.1177/0038026120954785.

Cole, Alyson. 2016. "All of Us Are Vulnerable, But Some Are More Vulnerable than Others: The Political Ambiguity of Vulnerability Studies, an Ambivalent Critique." Critical Horizons 17 (2): 260-277. https://doi.org/10.1080/14409917.2016.1153896.

Couldry, Nick ja Jun Yu. 2018. “Deconstructing datafication's brave new world." New media and Society 20 (12): 4473-4491. https://doi.org/10.1177/1461444818775968.

van Deursen, Alexander, Alex van der Zeeuw, Pia de Boer, Giedo Jansen ja Thomas van Rompay. 2021. "Digital inequalities in the Internet of Things: differences in attitudes, material access, skills, and usage." Information, Communication Q Society 24 (2): 258-276. Saatavilla: https://doi.org/10.1080/1369118X.2019.1646777

van Dijck, José. 2014. "Datafication, dataism and dataveillance: Big Data between scientific paradigm and ideology." Surveillance Q Society 12 (2): 197-208. https://doi.org/10.24908/ss.v12i2.4776.

Draper Nora A. ja Joseph Turow. 2019. "The corporate cultivation of digital resignation." New Media Q Society 21 (8): 1824-1839. https://doi.org/10.1177/1461444819833331.

Dencik, Lina. 2018. "Surveillance Realism and the Politics of Imagination: Is There No Alternative?" Krisis 1 (1): 31-43.

Dencik, Lina, Arne Hintz ja Jonathan Cable. 2016. “Towards data justice? The ambiguity of anti-surveillance resistance in political activism." Big Data Q Society 3 (2): 1-12. https://doi.org/10.1177/2053951716679678. 
Eubanks, Virginia. 2018. Automating Inequality: How High-Tech Tools Profile, Police and Punish the Poor. New York: St. Martin's Press.

Favaretto, Maddalena, Eva De Clercq ja Bernice Simone Elger. 2019. "Big Data and discrimination: perils, promises and solutions. A systematic review.” Journal of Big Data 6 (12): 1-27. https://doi.org/10.1186/s40537-019-0177-4.

Fineman, Martha Albertson. 2008. "The Vulnerable Subject: Anchoring Equality in the Human Condition." Yale Journal of LaW Q Feminism 20 (1): 1-17.

Firmino, Rodrigo, Bruno de Vasconcelos Cardoso ja Rafael Evangelista. 2019. "Hyperconnectivity and (Im) mobility: Uber and surveillance capitalism by the Global South." Surveillance Q Society 17 (1/2): $205-212$. https://doi.org/10.24908/ss.v17i1/2.12915.

Fotopoulou, Aristea. 2016. Feminist Activism and Digital Networks Between Empowerment and Vulnerability. London: Palgrave Macmillan. https://doi.org/10.1057/978-1-137-50471-5.

Gangadharan, Seeta Peña 2012. "Digital inclusion and data profiling." First Monday 17 (5).

Gilson, Erinn C. 2014. The Ethics of Vulnerability. A Feminist Analysis of Social Life and Practice. New York \& London: Routledge.

Ging, Debbie ja Eugenia Siapera. 2018. "Special issue on online misogyny." Feminist Media Studies 18 (4): 515-524. https://doi.org/10.1080/14680777.2018.1447345.

Gray, Jonathan, Carolin Gerlitz ja Liliana Bounegru. 2018. "Data infrastructure literacy." Big Data \& Society 5(2): 1-13. https://doi.org/10.1177/2053951718786316.

Goriunova, Olga. 2019. "Digital subjects: an introduction." Subjectivity 12: 1-11.

Hatuka, Tali ja Eran Toch. 2017. "Being visible in public space: The normalisation of asymmetrical visibility." Urban Studies 54 (4): 984-998. https://doi.org/10.1177/0042098015624384.

Heeks, Richard ja Shekhar Satyarupa. 2019. "Datafication, development and marginalised urban communities: an applied data justice framework." Information, Communication Q Society 22 (7): 992-1011. https://doi.org/10.1080/1369118x.2019.1599039.

Helsper, Ellen J. ja Bianca C. Reisdorf. 2017. "The emergence of a digital "underclass" in Great Britain and Sweden: Changing reasons for digital exclusion." New Media Q Society 19 (8): 1253-1270. https://doi.org/10.1177/1461444816634676.

Hermida, Alberto ja Víctor Hernández-Santaolalla. 2020. "Horizontal surveillance, mobile communication and social networking sites. The lack of privacy in young people's daily lives." Communication Q Society 33 (1): 139-152. https://doi.org/10.15581/003.33.1.139-152.

Hintz, Arne, Lina Dencik ja Karin Wahl-Jorgensen. 2018. Digital Citizenship in a Datafied Society. Cambridge \& Medford: Polity Press. https://doi.org/10.1007/s11616-019-00508-z.

Hjorth, Larissa ja Kathleen Cumiskey. 2018. "Mobiles Facing Death: Affective Witnessing and the Intimate Companionship of Devices." Cultural Studies Review 24 (2): 166-180.

https://doi.org/10.5130/csr.v24i2.6079.

Jameson, Shazade, Christine Richter ja Linnet Taylor. 2019. "People's strategies for perceived surveillance in Amsterdam Smart City." Urban Geography 40 (10): 1467-1484. https://doi.org/10.1080/02723638.2019.1614369.

Kamath, Anant. 2018. "'Untouchable' cellphones? Old caste exclusions and new digital divides in peri-urban Bangalore." Critical Asian Studies 50 (3): 375-394. https://doi.org/10.1080/14672715.2018.1479192.

Kennedy, Helen. 2018. "Living with Data: Aligning Data Studies and Data Activism Through a Focus on Everyday Experiences of Datafication." Krisis 1 (1): 18-30.

Keymolen, Esther ja Astrid Voorwinden. 2020. "Can we negotiate? Trust and the rule of law in the smart city paradigm." International Review of Law, Computers Q Technology 34 (3): 233-253. https://doi.org/10.1080/13600869.2019.1588844.

Keymolen, Esther ja Simone Van der Hof. 2019. "Can I still trust you, my dear doll? A philosophical and legal exploration of smart toys and trust." Journal of Cyber Policy 4 (2): 143-159.

https://doi.org/10.108o/23738871.2019.1586970.

Kitchin, Rob. 2014. “Big Data, new epistemologies and paradigm shifts.” Big Data Q Society 1 (1): 1-12. https://doi.org/10.1177/2053951714528481.

Koivunen, Anu, Katariina Kyrölä ja Ingrid Ryberg. 2018. "Vulnerability as a political language." Teoksessa The Power of Vulnerability. Mobilising Affect in Feminist, Queer and Anti-Racist Media Cultures, toimittaneet Anu Koivunen, Katariina Kyrölä ja Ingrid Ryberg, 1-26. Manchester: Manchester University Press.

Kreiczer-Levy, Shelly ja Ronit Donyets-Kedar. 2019. “Better Left Forgotten: An Argument Against Treating Some Social Media and Digital Assets as Inheritance in an Era of Platform Power." Brooklyn Law Review 84 (3): 703-744. 
Lagerkvist, Amanda ja Yvonne Andersson. 2017. "The grand interruption: death online and mediated lifelines of shared vulnerability." Feminist Media Studies 17 (4): 550-564. https://doi.org/10.1080/14680777.2017.1326554.

Lawson, Caitlin. 2018. Platform vulnerabilities: harassment and misogynoir in the digital attack on Leslie Jones. Information, Communication Q Society 21 (6): 818-833. https://doi.org/10.1080/1369118x.2018.1437203.

Lee, Ashlin. 2021. "Towards Informatic Personhood: understanding contemporary subjects in a data-driven society." Information, Communication Q Society 24 (2): 167-182. http://doi.org/10.1080/1369118X.2019.1637446.

Livingstone, Sonia ja Amanda Third. 2017. "Children and young people's rights in the digital age: An emerging agenda." Television Q New Media 19 (5): 657-670. https://doi.org/10.1177/1461444816686318.

Lomborg, Stine, Lina Dencik ja Hallvard Moe. 2020. "Methods for Datafication, Datafication of Methods: Introduction to the Special Issue." European Journal of Communication 35 (3): 203-212. https://doi.org/10.1177/0267323120922045.

Lupton, Deborah. 2019. Data selves: More-than-human perspectives. Cambridge: Polity.

Lupton, Deborah ja Mike Michael. 2017. “'Depends on Who's Got the Data': Public Understandings of Personal Digital Dataveillance." Surveillance Q Society 15 (2): 254-268. https://doi.org/10.24908/ss.v15i2.6332.

Lupton, Deborah ja Ben Williamson. 2017. "The datafied child: The dataveillance of children and implications for their rights." New Media Q Society 19 (5): 780-794. https://doi.org/10.1177/1461444816686328.

Lutz, Cristoph 2019. "Digital inequalities in the age of artificial intelligence and big data." Human Behavior and Emerging Technologies 1 (2): 141-148. https://doi.org/10.1002/hbe2.140.

Loubere, Nicholas. 2017. “China's internet finance boom and tyrannies of inclusion.” China Perspectives 4: 9-18. https://doi.org/10.4000/chinaperspectives.7454.

MacAulay, Margaret. 2019. "Antiviral Marketing: The Informationalization of HIV Prevention." Canadian Journal of Communication 44 (2): 239-261. http://doi.org/10.22230/cjc.2019v44n2a3331.

Mackenzie, Catriona, Wendy Rogers ja Susan Dodds. 2014. "Introduction: What is vulnerability and why does it matter to moral theory?" Teoksessa Vulnerability. New Essays in Ethics and Feminist Philosophy, toimittaneet Catriona Mackenzie, Wendy Rogers ja Susan Dodds, 1-32. Oxford: Oxford University Press.

Mackenzie, Catriona. 2014. "The importance of relational autonomy and capabilities for an ethics of vulnerability." Teoksessa Vulnerability. New essays in ethics and feminist philosophy, toimittaneet Catriona Mackenzie, Wendy Rogers ja Susan Dodds, 33-59. Oxford: Oxford University Press.

Marlin-Bennett, Renée. 2016. "Everyday rules and embodied information: anti-money laundering/counter-terrorist financing practices and radio frequency identification tags as security politics." Critical Studies on Security 4 (2): 169-186. https://doi.org/10.1080/21624887.2016.1160199.

Miller, Vincent. 2019. "The ethics of digital being: Vulnerability, invulnerability and 'dangerous surprises'." Teoksessa Digital Existence: Ontology, Ethics and Transcendence in Digital Culture, toimittanut Amanda Lagerkvist, 171-186. London: Routledge. https://doi.org/10.4324/9781315107479-9.

Mäkinen, Katariina. 2020. "Resilience and vulnerability: Emotional and affective labour in mom blogging." New Media Q Society. July 2020. https://doi.org/10.1177/1461444820941196.

Nikander, Pirjo ja Minna Zechner. 2006. “Ikäetiikka ja elämänkulun ääripäät, haavoittuvuus ja eettiset kysymykset." Yhteiskuntapolitiikka 71 (5): 515-526.

Ponzanesi, Sandra. 2019. "Migration and Mobility in a Digital Age: (Re)Mapping Connectivity and Belonging." Television Q New Media 20 (6): 547-557. https://doi.org/10.1177/1527476419857687.

Ruckenstein, Minna ja Julia Granroth. 2020. "Algorithms, advertising and the intimacy of surveillance." Journal of Cultural Economy 13 (1): 12-24. https://doi.org/10.1080/17530350.2019.1574866.

Ruohonen, Jukka, Sami Hyrynsalmi ja Ville Leppänen. 2020. "A mixed methods probe into the direct disclosure of software vulnerabilities." Computers in Human Behavior, 103: 161-173. https://doi.org/10.1016/j.chb.2019.09.028.

Salminen, Ari. 2011. Mikä kirjallisuuskatsaus?: Johdatus kirjallisuuskatsauksen tyyppeihin ja hallintotieteellisiin sovelluksiin. Opetusjulkaisuja 62, Vaasan yliopiston julkaisuja. Vaasa: Vaasan yliopisto.

Schram, Brian. 2019. "Accidental Orientations: Rethinking Queerness in Archival Times." Surveillance Q Society 17 (5): 602-617. https://doi.org/10.24908/ss.v17i5.8688.

Schwartz, Margaret. 2019. "Thrownness, vulnerability, care. A feminist ontology for the digital age." Teoksessa Digital Existence: Ontology, Ethics and transcendence in Digital Culture, toimittanut Amanda Lagerkvist, 81-99. London: Routledge. https://doi.org/10.4324/9781315107479-4.

Schoemaker, Emrys, Dina Baslan, Bryan Pon ja Nicola Dell. 2021. "Identity at the margins: data justice and refugee experiences with digital identity systems in Lebanon, Jordan, and Uganda." Information Technology for Development 27 (1): 13-36. http://doi.org/10.1080/02681102.2020.1785826. 
Seaver, Nick. 2017. "Algorithms as culture: Some tactics for the ethnography of algorithmic systems." Big Data Q Society 4 (2): 1-12. https://doi.org/10.1177/2053951717738104.

Shklovski, Irina, Scott D. Mainwaring, Halla Hrund Skúladóttir ja Höskuldur Borgthorsson. 2014. "Leakiness and Creepiness in App Space: Perceptions of Privacy and Mobile App Use." CHI '14: Proceedings of the SIGCHI Conference on Human Factors in Computing Systems.

Shabbar, Andie. 2018. "Queer-Alt-Delete: Glitch Art as Protest Against Surveillance Cis-tem." Women's Studies Quarterly 46 (3\&4): 195-211. https://doi.org/10.1353/wsq.2018.0039.

Sirkkunen, Esa. 2016. "Yksityisyys valvonnan verkoissa." Media Q viestintä 39 (2): 117-136. https://doi.org/10.23983/mv.61429.

Smith, Gavin JD. 2018. "Data doxa: The affective consequences of data practices.” Big Data Q Society (January 2018): 1-15. https://doi.org/10.1177/2053951717751551.

Sourbati, Maria ja Frauke Behrendt. 2020. "Smart mobility, age and data justice." New Media Q Society (February 2020): 1-17. Saatavilla: https://doi.org/10.1177/1461444820902682.

Steedman, Robin, Helen Kennedy ja Rhianna Jones. 2020. "Complex ecologies of trust in data practices and datadriven systems." Information, Communication Q Society 23 (6): 817-832. https://doi.org/10.1080/1369118x.2020.1748090.

Sumartojo, Shanti, Sarah Pink, Deborah Lupton ja Christine Heyes LaBond. 2016. "The affective intensities of datafied space." Emotion, Space and Society, 21: 33-40, https://doi.org/10.1016/j.emospa.2016.10.004.

Taylor, Linnet. 2020. "The price of certainty: How the politics of pandemic data demand an ethics of care." Big Data Q Society 7 (2): 1-7. https://doi.org/10.1177/2053951720942539.

Thornham, Helen. 2019. "Algorithmic vulnerabilities and the datalogical: Early motherhood and tracking-as-care regimes." Convergence 25 (2): 171-185. https://doi.org/10.1177/1354856519835772.

Triggs, Anthony Henry, Kristian Møller ja Christina Neumayer. 2021. "Context collapse and anonymity among queer Reddit users." New Media \& Society 23 (1): 5-21. https://doi.org/10.1177/1461444819890353.

Valentine, Sarah. 2019. "Impoverished Algorithms: Misguided Governments, Flawed Technologies, and Social Control." Fordham Urban Law Journal 46 (2): 364-427.

Vannini, Sara, Bryce Clayton Newell ja Ricardo Gomez 2019. “'Mind the Five': Guidelines for Data Privacy and Security in Humanitarian Work With Undocumented Migrants and Other Vulnerable Populations." Journal of the Association for Information Science and Technology 71 (8): 927-938. https://doi.org/10.1002/asi.24317.

Virokannas, Elina, Suvi Liuski ja Marjo Kuronen. 2020. "The contested concept of vulnerability - a literature review." European Journal of Social Work 23 (2): 327-339. https://doi.org/10.1080/13691457.2018.1508001.

Wahl-Jorgensen, Karin, Lucy Bennett ja Gregory Taylor. 2017. "The Normalization of Surveillance and the Invisibility of Digital Citizenship: Media Debates After the Snowden Revelations." International Journal of Communication 11: 740-762. 